\title{
The Application of International Law in the Court of Justice of the European Union: Proportionality Rising
}

\author{
Rupert Dunbar* \\ Department of Law, Kingston University, Surrey, England \\ ${ }^{\star}$ Corresponding author: Rupert.Dunbar@kingston.ac.uk
}

(Received 16 July 2020; accepted 16 November 2020)

\begin{abstract}
Application of international treaty and customary international law at the Court of Justice of the European Union (CJEU) is increasingly recognized by scholars as problematic regarding legal certainty. This Article seeks to illustrate why this is and to propose reform. Through comparing judicial approaches in the application of international law at the CJEU to its approach in internal case law, it is argued that in the frequent absence of proportionality in external case law the Court has utilized, redeployed, or varied other judicial devices in an effort to retain the discretion which proportionality affords. These are argued to effect legal certainty and established concepts of justice within the EU legal system. Accordingly, it is submitted that proportionality should be transplanted fully and openly to external relations case law and that support for this can be extrapolated from existing literature.
\end{abstract}

Keywords: External relations case law; proportionality; direct effect; legal certainty; international law

\section{A. Introduction}

Proportionality is the predominant tool for resolving cases in EU law. ${ }^{1}$ Areas in which its role is excluded or limited are few, ${ }^{2}$ however, case law applying international law-external relations case law-has emerged as one. Proportionality ensures that a given action does not go beyond what is necessary and does not infringe unacceptably on other rights or legitimate aims. Its impact on the EU legal system is notable; norms of EU law emerge as non-hierarchical, with the potential for each to prove most important in the unique facts of a given case. ${ }^{3}$ This enables the Court to manage and develop norms within EU law and provides it significant discretion too.

The large absence of proportionality in external relations case law means that a significant mechanism for resolving disputes is missing. The result has been a strict hierarchy in which supposedly mechanical rules govern when international law can be relied upon. The reality is very different though; scholars have become increasingly vocal in exposing the Court's discretion and

Dr. Dunbar is currently a senior lecturer at Kingston University's School of Law, Social and Behavioral Sciences. His research currently concerns the relationship between international and domestic law, debating and testing notions of justice, and legal certainty in domestic courts' case law. His PhD criticized the current approaches adopted by the Court of Justice of the European Union for applying international law within the EU legal system.

${ }^{1}$ Gunnar Beck, The Legal Reasoning of the Court of Justice of the EU 347 (2012).

${ }^{2}$ Takis Tridimas, General Principles of EU Law 136-38 (2d ed. 2006). See also Opinion of Advocate General Jacobs at 1533, ECJ, Case C-120/94, Comm'n v. Greece, ECLI:EU:C:1995:109 (Apr. 6, 1995), http://curia.europa.eu/juris/liste.jsf? language $=$ en $\&$ num $=\mathrm{C}-120 / 94$.

${ }^{3}$ For example, free movement, fundamental rights, environmental protection, et cetera. 
activism in external relations case law. ${ }^{4}$ But discretion here, unlike proportionality in internal case law, is fragmented and manifests itself across inter alia rules of reliance, especially the direct effect test, opportunistic approaches to interpretation, and recourse to the concept of autonomy.

This significantly influences legal certainty, which the Court has called a "fundamental principle of Community law." It recognizes that legal certainty, "requires, in particular, that rules should be clear and precise, so that individuals may ascertain unequivocally what their rights and obligations are and may take steps accordingly." "We will see that external case law falls far short of this aim, affecting participants.

This is particularly problematic given that legal certainty and justice are all that law ought to achieve. ${ }^{7}$ A significant shortcoming in one is concerning, as they are, "a couple that cannot be ignored in a functioning and legitimate system of Law." ${ }^{8}$ However, our analysis will also reveal issues in external case law concerning justice, by which is meant, achieving the right outcome in a given case.

Substantive, or "thick," justice is contestable, but "thin" justice is widely accepted. Thin justice can be derived from Aristotle $e^{9}$ and amounts to the assertion that "like cases should be treated alike and unalike cases unalike to the extent of their unalikeness." 10 Through comparing internal and external case law we will be well-placed to see that fundamental aspects of the EU legal system are modified in external case law. This is so despite the Court stating that "an international agreement cannot affect the allocation of responsibilities defined in the Treaties"11 and asserting that international law is "an integral part of [EU] law." ${ }^{2}$ It will be argued that fundamental changes largely flow as a result of the large absence of proportionality in external case law. The extent of "unalikeness"-which would justify divergence from internal case law-and the consequent exclusion of proportionality will be challenged, particularly given that general principles of EU law are anticipated to have relevance "in a series of infinite applications of the law," proportionality and other general principles have on occasion been applied in external case law.

\footnotetext{
${ }^{4}$ See Mario Mendez, The Legal Effects of EU Agreements: Maximalist Treaty Enforcement and Judicial Avoidance Techniques (2013); Mario Mendez, The Legal Effect of Community Agreements: Maximalist Treaty Enforcement and Judicial Avoidance Techniques, 21 Eur. J. INT'L L. 83 (2010).

${ }^{5}$ See ECJ, Case C-308/06, Intertanko and Others, ECLI:EU:C:2008:312 (June 3, 2008), para. 69, http://curia.europa.eu/juris/ liste.jsf?language $=$ en\&num $=$ C-308/06. See also ECJ, Case C-344/04, IATA and ELFAA, ECLI:EU:C:2006:10 (Jan. 10, 2006), para 68, http://curia.europa.eu/juris/liste.jsf?language=en\&num=C-344/04.

${ }^{6}$ ECJ, Case C-366/10, Air Transport Association of America and Others, ECLI:EU:C:2011:864 (Dec. 21, 2011), para. 68, http://curia.europa.eu/juris/liste.jsf?language=en\&num $=$ C-366/10.

${ }^{7}$ Joseph Raz, Legal Principles and the Limits of Law, 81 YALE L.J. 823, 841 (1972); LoRd Denning, The Discipline OF LAW 293 (1979); Jürgen Habermas, Between Facts and Norms 199 (William Rehg trans., 1997); Stefano Bertea, Certainty, Reasonableness and Argumentation in Law, 18 Argumentation 465, 475 (2004); Robert Alexy, The Dual Nature of Law, 23 Ratio Juris 167 (2010); William Twining, Karl Llewellyn and the Realist Movement 157 (2d ed. 2012); and BECK, supra note 1 , at 274 .

${ }^{8}$ Bertea, supra note 7 , at 475 .

${ }^{9}$ Aristotle, The Nicomachean Ethics 80-88 (David Ross trans., Oxford University Press 2009).

${ }^{10}$ See, e.g., C.H. Perelman, Justice 21-24 (1967); Kenneth I. Winston, On Treating Like Case Alike, 62 CAlif. L. Rev. 1, 22 (1974); R.M. Hare, Moral Thinking: Its Levels, Method and Point 157 (1981); H.L.A. Hart, The Concept of LaW 159 (3d ed. 2012); Gerard Conway, The Limits of Legal Reasoning and the European Court of Justice 244 (2012); and SiOnAidh DOUglas-Scott, LAW AFTer MOdernity 185 (2013).

${ }^{11}$ See, e.g., ECJ, Case C-459/03, Commission v Ireland, ECLI:EU:C:2006:345 (May 30, 2006), para 123, http://curia.europa eu/juris/liste.jsf?language $=$ en\&num $=$ C-459/03. See also Joined Cases C-402/05 P and C-415/05 P, Kadi \& Al Barakaat Int'l Found. v. Council and Comm'n, ECLI:EU:C:2008:461 (Sep. 3, 2008), para. 282, https://curia.europa.eu/juris/liste.jsf?oqp= $\&$ for $=\& \mathrm{mat}=$ or $\&$ je $=\& \mathrm{td}=\% 3 \mathrm{BALL} \& \mathrm{jur}=\mathrm{C} \% 2 \mathrm{CT} \% 2 \mathrm{CF} \& \mathrm{num}=402 \% 252 \mathrm{~F} 05 \&$ page $=1 \&$ dates $=\& \mathrm{pcs}=\mathrm{Oor} \& \mathrm{lg}=\& \mathrm{pro}=\& \mathrm{mat}=$ or\&cit=none $\% 252 \mathrm{CC} \% 252 \mathrm{CCJ} \% 252 \mathrm{CR} \% 252 \mathrm{C} 2008 \mathrm{E} \% 252 \mathrm{C} \% 252 \mathrm{C} \% 252 \mathrm{C} \% 252 \mathrm{C} \% 252 \mathrm{C} \% 252 \mathrm{C} \% 252 \mathrm{C} \% 252 \mathrm{C} \% 252 \mathrm{C} \% 252 \mathrm{Ctrue}$ $\% 252$ Cfalse $\% 252$ Cfalse\&language $=$ en $\&$ avg $=\&$ cid $=12821209$.

${ }^{12}$ ECJ, Case C-181/73, Haegeman v. Belgium, ECLI:EU:C:1974:41 (Apr. 30, 1974), para. 5, http://curia.europa.eu/juris/liste jsf?language $=$ en $\&$ num $=\mathrm{C}-181 / 73$.

${ }^{13}$ Tor-Inge Harbo, The Function of the Proportionality Principle in EU Law, 16 EUR. L.J. 158, 159 (2010) (citing NICHOLAS Emiliou, The Principle of Proportionality in EU Law: A Comparative Study 115 (1996)).
} 
The need for the Court to address shortcomings in this area is reflected in the mass of proposals from scholars for reform. However, proportionality has received little sustained attention in literature concerning external relations case law. It is submitted, though, that scholars' proposals for reform—-somewhat like the Court's approaches in external relations case law-often converge towards proportionality without fully arriving there. Accordingly, this Article offers an initial exploration of the possibility for extension of proportionality, in its full form, to external relations case law. It seems this could both improve legal certainty and form a more just basis for the application of international law in the CJEU moving forward.

This Article is structured as follows: First, a lack of legal certainty and the necessity of balancing EU law and interests against international law in external relations case law will be highlighted in prominent scholarship, with proportionality identified as warranting closer attention; second, the context and prominence of the application of proportionality in internal case law will be analyzed; third, the absence of proportionality in external relations case law will be analyzed and reflected upon through consideration of the judicial tools which have been deployed to facilitate discretion in its stead. This Article concludes with the pragmatic call for proportionality to be deployed more openly, frequently and fully in external relations case law.

\section{B. The Rise of Proportionality in External Relations Case Law Scholarship?}

\section{The Acknowledged Need for Reform of External Relations Case Law}

Scholarship can be drawn upon to confirm two primary observations regarding external relations case law: First, legal certainty is problematic, and second, the case law evidences some balancing of EU law/interests against international law. The former is important, as the "dual nature" of law suggests that legal certainty, which is defined as being able to anticipate an outcome, and justice, which is defined as achieving the right outcome in a given case, are all law ought to achieve. ${ }^{14}$ In lieu of an authoritative balance between these aims one would need to be cautious in proposing reforms. However, due to shortcomings in legal certainty, scholars have been liberated in proposing modifications to the Court's approach, with most favoring a continuance of the balance between EU and international law already present, but in modified form. Surprisingly though, only a few scholars mention proportionality expressly, and those do so only briefly.

\section{Concerns Regarding Legal Certainty in External Relations Case Law}

Concerning legal certainty in the case law, Holdgaard speaks of a "manifest lack of clarity and coherence," 15 Skordas of "counter-systemic commotion," 16 and Odermatt encourages "a more consistent and principled approach when dealing with international law questions." 17 Etienne notes " $[u]$ ncertainty" concerning the application of customary international law and direct effect of international agreements, ${ }^{18}$ and then calls on the Court generally to say "what it is actually doing and how it is doing [it]." 19 Mendez criticizes the "curt and formalistic" reasoning in Intrertanko and draws attention to the fact that, concerning the direct effect test, "we are entitled

\footnotetext{
${ }^{14}$ Robert Alexy, The Dual Nature of Law, 23 RAtio JuRIS 167 (2010). See also Joseph Raz, Legal Principles and the Limits of Law, 81 YALE L.J. 823, 841 (1972); DENNING, supra note 7, at 293; HABERMAS, supra note 7, at 199; Bertea, supra note 7, at 475; TWINING, supra note 7, at 157; and BECK, supra note 1, at 274.

${ }^{15}$ Raas Holdgaard, External Relations Law of the European Community: Legal Reasoning and Legal DisCOURSES 235 (2008).

${ }^{16}$ Achilles Skordas, Völkerrechtsfreundlichkeit as Comity and the Disquiet of Neoformalism: A Response to Jan Klabbers, in European Foreign Policy: Legal and Political Perspectives 116 (Panos Koutrakos ed., 2011).

${ }^{17}$ Jed Odermatt, The Court of Justice of the European Union: International or Domestic Court?, 3 Cambridge J. Int'l \& Comp. L. 696, 702 (2014).

${ }^{18}$ Judicaël Etienne, Loyalty Towards International Law as a Constitutional Principle of EU Law? 14 (Jean Monnet Working Paper Series, 03/2011, 2011), http://jeanmonnetprogram.org/wp-content/uploads/2014/12/110301.pdf (last accessed Apr. 30, 2021).

${ }^{19} I d$. at 39.
} 
to expect a credible attempt at reasoned justification for why a particular Agreement will be deprived of its most potent internal legal effects." ${ }^{20}$ Intertanko is also highlighted by Koutrakos as evidence that the process of direct effect "may be unpredictable," ${ }^{21}$ whilst Air Transport is said to be "staggering in its brevity and lack of clarity." 22

Of course, criticisms of legal certainty will always be present, but they are particularly acute concerning the application of international law in the CJEU. Our analysis of external relations case law will confirm concerns of scholars regarding legal certainty; however, the absence of proportionality will be explained as the reason for this to a greater extent than has previously been undertaken - albeit most scholars favor some balance.

\section{Disposing of Two Possible Arguments in Favor of the Status Quo}

With legal certainty problematic, two possible avenues remain by which reform in external relations case law may not be desirable: First, were this construct to be required by international law itself, and second, were the case law as it currently stands to benefit the EU-for instance, through a continuing projection of the "good citizen Europe" brand. ${ }^{23}$

First, it is submitted that international law does not generally dictate the effects which it shall have in domestic legal systems. ${ }^{24}$ The Danzig ${ }^{25}$ case of the Permanent Court of International Justice provides a notable exception, but one which was ultimately based on "the very object of [that] international agreement, according to the intention of the contracting Parties," and which the Court recognized went against "a well-established principle of international law ... [that] an international agreement, cannot, as such, create direct rights and obligations for private individuals." ${ }^{26}$ The narrow exception has not been returned to, indicating its exceptional nature. ${ }^{27}$ The more recent $L a G r a n d^{28}$ and Avena ${ }^{29}$ cases arguably indicate the limited relevance of Danzig moving forward. Both concerned Article 36 of the Vienna Convention on Consular Relations, which allows consulates access to detainees and which the US was accused of breaching. But even in the face of such specific links to individuals it has been recognized the International Court of Justice did "not stipulate or imply, that the US courts are required to give direct effect to the obligation." 30 It is thus, widely acknowledged by scholars that there is not an obligation to apply international law domestically. ${ }^{31}$ This has been suggested to apply equally to UN Security Council Resolutions, arguably the most binding of international legal instruments and so, one might think, more prone to direct effect. ${ }^{32}$ Of course, the scope for maneuver provided by international law has manifested

\footnotetext{
${ }^{20}$ MendeZ, supra note 4 , at 319.

${ }^{21}$ Panos Koutrakos, EU International Relations Law 266 (2d ed. 2015).

${ }^{22} I d$. at 317.

${ }^{23}$ For use of this term see Tim Dunne, Good Citizen Europe, 84 International Affairs 13 (2008).

${ }^{24} \mathrm{On}$ the interesting and seemingly expanding practice of EU agreements expressing when they will not have direct effect, see Narine Ghazaryan, Who are the 'Gatekeepers'?: In Continuation of the Debate on the Direct Applicability and Direct Effect of EU International Agreements, 37 Y.B. EuR. L. 27 (2018).

${ }^{25}$ Jurisdiction of the Courts of Danzig (Pecuniary Claims of Danzig Railway Officials who have Passed into the Polish Service, against the Polish Railways Administration), Advisory Opinion, 1928 P.C.I.J. (ser. B) No. 15.

${ }^{26} I d$. at $17-18$.

${ }^{27}$ André Nollkaemper, National Courts and the International Rule of Law 125 (2011).

${ }^{28}$ LaGrand Case (Ger. v. U.S.), Judgment, 2001 I.C.J. 466 (June 27).

${ }^{29}$ Avena and Other Mexican Nationals (Mex. v. U.S.), Judgment, 2004 I.C.J. 12 (March 31).

${ }^{30}$ NolLKAEMPER, supra note 27 , at 11 .

${ }^{31}$ Yuval Shany, Toward a General Margin of Appreciation Doctrine in International Law?, 16 EUR. J. INT'L L. 907 (2006); Jean d'Aspremont \& Frédéric Dopagne, Kadi: The ECJ's Reminder of the Elementary Divide Between Legal Orders, 5 INT'L Orgs. L. Rev. 371 (2008); NollKaemper, supra note 27, at 11, 120, 299-304; André Nollkaemper, The Duality of Direct Effect, 25 EUR. J. INT'L L. 105, 122 (2014).

${ }^{32}$ Christina Eckes, EU-Counter Terrorist Policies and Fundamental Rights 233 (2009); Matthias Forteau, The Role of the International Rules of Interpretation for the Determination of Direct Effect of International Agreements, in THE INTERPRETATION OF INTERNATIONAL LAW By DOMEstic COURTS: Unity, Diversity AND CONVERGENCE 99 (Helmut
} 
itself in the EU through its own tests of direct effect and its utilization of the concept of an autonomous legal system which, "cannot be prejudiced by an international agreement." 33 Accordingly, discretion is both afforded and already taken, as we will see immediately below, and when considering external relations case law more fully, but direct effect and autonomy have not proven satisfactory utilizations of it.

Second, accepting that the perception other nations and parties may have is important to international standing, including the capacity to function effectively on the international plane, the Court's case law still falls short. ${ }^{34}$ Ultimately, remarkably few scholars are supportive of the current external relations case law of the CJEU without equivocation. ${ }^{35}$ For instance, the 2008 cases, Intertanko and Kadi, have been described as an annus horribilis for the Court, showcasing the declining perception of its open approach towards international law. ${ }^{36}$ Such views have even become mainstream; Goldsmith and Posner's brief — and very negative-appraisal of the Court's case law appeared in the Wall Street Journal. ${ }^{37}$

With external relations case law at a remarkably low ebb concerning its utility in raising the esteem in which the EU is held, problems regarding legal certainty, and international law providing discretion for domestic courts in applying international law, it is not surprising that many suggestions for reform have been forthcoming. ${ }^{38}$ These can now be considered.

\section{Acknowledgement of the Need for Balance Between Protection of EU Law and Respect for International Law in the Interests of Justice}

In their analyses of external relations case law, scholars tend to arrive at an abrogated position between respecting international law and protecting/promoting EU law/interests. This is achieved either through recognizing and endorsing elements of balance within current case law or proposing such a balance more generally.

Accordingly, it has been noted that "the Court case-law reflects the balanced relationship between international law and EU law,"39 "[t]he Court is still trying to find a balance between protecting the autonomy of its own legal order and the openness towards international law that

Phillip Aust \& Georg Nolte eds., 2016). Contra Erika de Wet \& Jure Vidmar, Conclusions, in HiERARCHY IN INTERNATIONAL Law: The Place of Human Rights 304 (Erika de Wet \& Jure Vidmar eds., 2012).

${ }^{33}$ Kadi and Al Barakaat International Foundation v. Council and Commission, Joined Cases C-402/05 P and C-415/05 P 316.

${ }^{34}$ For discussion see Louis Henkin, How Nations Behave (2d ed. 1968); Harold Hongju Koh, Why Do Nations Obey International Law?, 106 YALe L.J. 2599 (1997); Andrew T. Guzman, A Compliance-Based Theory of International Law, 90 Calif. L. Rev. 1823 (2002); and Jack L. Goldsmith \& Erik A. Posner, The Limits of International Law (2007).

${ }^{35}$ But see Eileen Denza, Placing the European Union in International Context: Legitimacy of the Case Law, in JUDGING Europe's Judges (Maurice Adams et al. eds., 2013). Pieter Jan Kuijper, "It Shall Contribute to ... the Strict Observance and Development of International Law... ", in The Court of Justice AND The Construction of Europe: ANAlyses and Perspectives on SiXty Years of Case-law 611 (2013) (concluding that "[a] lot of critique has been lavished on the Court ... much of this critique seems exaggerated”). However, Jan Kuijper's contribution was to the Court's sixth anniversary publication of essays and one ought not to be too rude to one's host. And he did point out that "the Court perhaps needs to improve its treatment of binding decisions of (other) international courts and tribunals." Id. at 611.

${ }^{36}$ Matthias Kottmann, Introvertierte Rechtsgemeinschaft 233 (2014).

${ }^{37}$ Jack Goldsmith \& Eric Posner, Does Europe Believe in International Law? Based on the record it has no grounds to criticize the U.S., WALl STREeT Journal (Nov. 25, 2008), http://www.wsj.com/articles/SB122757164701554711 (last accessed Apr. 30, 2021).

${ }^{38}$ On treatment of the CJEU as a domestic court, see Piet Eeckhout, Community Terrorism Listings, Fundamental Rights, and UN Security Council Resolutions: In Search of the Right Fit, 3 EUR. ConsT. L. REv. 183, 196 (2007); Daniel Halberstam, Local, Global and Plural Constitutionalism: Europe Meets the World, in THE WorLds of European CONSTITUTIONALISM 198 (Gráinne de Búrca \& J.H.H. Weiler eds., 2012); Allen Rosas, International Responsibility of the EU and the European Court of Justice, in International Responsibility of the European Union: European and International Perspectives 159 (Malcolm Evans \& Panos Koutrakos eds., 2013); Helmut Philipp Aust, Alejandro Rodiles \& Peter Staubach, Unity or Uniformity? Domestic Courts and Treaty Interpretation, 27 Leiden J. Int'l L. 75, 100 (2014).

${ }^{39}$ Etienne, supra note 18 , at 2. 
is enshrined in the EU Treaties," 40 and that within the case law there is "commitment to comply with international law and the defence of EU autonomy." 41

In accommodating this balance moving forward, Cannizzarro suggests neo-monism as a concept which can "mitigate some of the consequences deriving from the supremacy of international law." ${ }^{2}$ de Búrca suggests a "soft constitutionalist approach . . . which does not insist on a clear hierarchy of rules but rather on commonly negotiated and shared principles for addressing conflict." ${ }^{43}$ Klabbers adopts the term Völkerrechtsfreundlichkeit to mean the EU respecting international law on the international plane and to "apply it in the internal legal order if and when appropriate." 44 In the same collection of essays Skordas responds to Klabbers. For Skordas, Völkerrechtsfreundlichkeit as comity ${ }^{45}$ functions as an ersatz meta-principle that enables the ECJ to recognize, interpret, and implement international law and, at the same time, develop and preserve the Union's own separate identity. ${ }^{46}$ Comity, Skordas states, "has a hybrid status, oscillating between social [local] practice and a 'sense of international legal obligation." 47 All of these proposals have at their heart a balance between international law and EU law.

More precise proposals for the mechanics of this balance are also forthcoming in scholarship. Etienne considers that the Court "has opened the doors when international law commanded so and in turn has closed them when the integrity of essential EU acquis was at stake." However, the extent to which only the essential EU acquis has been protected from the application of international law in the case law will appear below as debatable. Etienne proposes, moving forward at least, that meta-constitutional principles of EU law should be shielded from international law. These are, " ... the rules inherent to the fundaments of the European Union, providing for the essential values on which it is founded, [and] the general principles on its institutional framework and on its relationships with the member states and the international legal system." ${ }^{8}$

The argument put forward implies that material, or policy, provisions of primary law are subordinate and would not form a part of this cluster. ${ }^{49}$ Martines notes that "[t]here is of course a risk in approaching international law binding the EU selectively which can result in the very denial of international law, if pushed too far," the EU provides a way of protecting its legal order. ..."51 One aspect of Martines' suggestion arguably comes very close to proportionality, "[w]hat could be called the sub-constitutional supremacy of international law means that the incompatibility of an agreement's provision with primary law might be a limit to the direct application of its provisions." ${ }^{2}$

Accordingly, this proposal is more liberal in balancing EU interests than that of Etienne and has a strong flavor of proportionality, without deploying that term. Overall, prevarication is palpable in putting into print the "p word." Eeckhout though does suggest that "general principles of EU law, such as the principle of proportionality" are an alternative to "putting up formal obstacles,

\footnotetext{
${ }^{40}$ Odermatt, supra note 17 , at 718.

${ }^{41}$ Francesca Martines, Direct Effect of International Agreements of the European Union, 25 EUR. J. INT'L L. 129, 144 (2014).

${ }^{42} I d$. at 52 .

${ }^{43}$ Gráinne de Búrca, The European Court of Justice and the International Legal Order After Kadi, 51 HaRv. L. REv. 1, 39 (2010).

${ }^{44}$ Jan Klabbers, Völkerrechtsfreundlichkeit? International law and the Union Legal Order, in EUROPEAN FOREIGN POLICY: Legal and Political Perspectives 98 (Panos Koutrakos ed., 2011).

${ }^{45}$ Contrasted with hierarchy and presented implicitly as the opposite. $I d$. at 116 .

${ }^{46}$ Skordas, supra note 16 , at 142 .

${ }^{47} I d$. at 126.

${ }^{48}$ Etienne, supra note $18,34$.

${ }^{49}$ See id. at 34 ("Meta-constitutional rules would relate to these general principles on principles of primary law, simultaneously overarching and providing the European Union with the essence of its constitutional structure."). See also id. at 33 ("It is obvious and common sense that Articles on the basic functioning of the Union do not have the same scope that material provisions on the Union policies have.").

${ }^{50}$ Martines, supra note 41 , at 145 .

${ }^{51} I d$.

${ }^{52} \mathrm{Id}$. at 146.
} 
such as the lack of direct effect of an international agreement." 53 "[T] Eeckhout] that ... the Court should more readily accept direct effect but show reluctance to find a breach [of international law] where EU legislation is concerned" 54 was also noted by Mendez. These passages remain - to the author's knowledge-the strongest endorsement of proportionality proper in the application of international law in the CJEU to date.

\section{Proportionality's Place in the Literature and Potential Moving Forward}

Like a missing jigsaw piece, it is submitted that proportionality fits neatly into the literature.

First, it can accommodate the aim sought by most scholars of achieving a balance between respect for international law and protection of EU law. This balance is now more clearly encapsulated in the Treaties too, with Article 3(5) of the Treaty of the European Union (TEU) requiring strict observance of international law, but also that the EU uphold and promote its values and interests.

The second way in which proportionality meets the aims of scholars is that its deployment would place less pressure on tests for direct effect of international law, which have given rise to the legal uncertainty to which scholars have objected. The process by which direct effect has become an awkward locus for discretion in the absence of proportionality in external relations case law will be further detailed below.

The third benefit of proportionality is its familiarity and durability. With the proliferation of nomenclatures in external relations case law analyses there is the risk that scholars may speak past one another, whereas coalescence around proportionality can provide a more solid basis for development. Relevant elements of proportionality will be considered more fully below, but it is notable that proportionality is durable in its application to a range of contexts-governing competence and subsidiarity, reviewing EU and Member State action for legitimacy of aims and appropriateness of measures, and even weighing interests against one another stricto sensu..$^{55}$ Its application in external relations case law could concern derogation from international law where an international treaty confers rights on individuals, but equally, due to proportionality's reach it need not be limited to this. For example, in case law not applying international law the question of direct effect does not arise concerning review of EU legislative action under Article 263 or 267 of the Treaty on the Functioning of the European Union (TFEU), permissibility of review is presumed, and the intensity of judicial review varies based on the complexity of the issue.

A fourth merit of proportionality is that of facilitating coherence with fundamental tenets of the EU legal system. The rule of law principle from Les Verts provides that, "in a Community based on the rule of law ... neither [the EU's] Member States nor its institutions can avoid a review of the question whether the measures adopted by them are in conformity with the basic constitutional charter, the Treaty." ${ }^{\circ 6}$

For EU external relations law the concept of a political question doctrine is not accepted, meaning that, in principle, the legislature's action should be reviewable. ${ }^{57}$ Practically, though, without

\footnotetext{
${ }^{53}$ Piet Eeckhout, EU External Relations Law 383 (2d ed. 2011).

${ }^{54}$ MENDEZ, supra note 4 , at 320 .

${ }^{55}$ See generally TRIDIMAS, supra note 2.

${ }^{56}$ ECJ, Case C-294/83, Parti Ecologiste Les Verts v. European Parliament, ECLI:EU:C:1986:166 (Apr. 23, 1986), para. 23, http://curia.europa.eu/juris/liste.jsf?language=en\&num=C-294/83.

${ }^{57}$ Piet Eeckhout, Does Europe's Constitution Stop at the Water's Edge?: Law and Policy in the EU's External Relations, 5 Walter VAn Gerven Lectures 1, 27 (2005). See also Opinion of Advocate General Maduro at paras. 34-40, ECJ, Joined Cases C-402/05 P and C-415/05 P Kadi \& Al Barakaat Int'l Found. v. Council \& Comm'n, ECLI:EU:C:2008:11 (Jan. 16, 2008), https://curia.europa.eu/juris/liste.jsf?oqp $=\&$ for $=\& m a t=$ or \&jge $=\& t d=\% 3 B A L L \& j u r=C \% 2 C T \% 2 C F \&$ num $=402 \% 252 \mathrm{~F} 05 \&$ page $=1 \&$ dates $=\& p c s=$ Oor $\& \lg =\&$ pro $=\&$ nat $=$ or $\&$ cit $=$ none $\% 252 \mathrm{CC} \% 252 \mathrm{CCJ} \% 252 \mathrm{CR} \% 252 \mathrm{C} 2008 \mathrm{E}$ $\% 252 \mathrm{C} \% 252 \mathrm{C} \% 252 \mathrm{C} \% 252 \mathrm{C} \% 252 \mathrm{C} \% 252 \mathrm{C} \% 252 \mathrm{C} \% 252 \mathrm{C} \% 252 \mathrm{C} \% 252 \mathrm{Ctrue} \% 252 \mathrm{Cfalse} \% 252 \mathrm{Cfalse} \&$ language $=\mathrm{en} \& \mathrm{avg}=\&$ cid $=12821209$.
} 
direct effect of international law the EU legislature-or less frequently Member State ${ }^{58}$ essentially has freedom to ignore it. ${ }^{59}$ This seems in tension with the concept of international law as an integral part of EU law and Article 3(5) TEU. Moreover, we will see that at present, direct effect of international law precludes, in the absence of proportionality, the defense of the legislature or Member State that pursues an objective in the Treaty which was, in the circumstances, more important than that of international law. Thus, international law can also, arguably, have too great an effect and it is notable that the Council in particular has sought to exclude direct effect from certain EU agreements. ${ }^{60}$ Proportionality can achieve review commensurate with complexity of circumstance, without excluding international law nor allowing it to overpower other EU norms. This would overcome the somewhat schizophrenic options currently available, whilst maintaining a closer correlation with recognized precepts of EU law.

Having made the case that proportionality warrants more sustained consideration in the literature, the following sections will consider how proportionality manages the relationship between other EU norms in internal case law. Reasons for it to be more fully and openly applied to external relations case law will then be developed in context.

\section{Judicial Discretion Manifests Itself Largely in Proportionality in Internal Case Law}

Claims to direct effect are arguably the distinctive feature of the EU legal order, and as a result, coverage is prominent. However, direct effect sits within further rules of reliance. It is notable, though, that all of these rules are remarkably lenient in allowing EU law to be invoked easily. Invocation of EU law is simply the beginning in most cases and-as "EU primary law [itself] is characterized by a high degree of vagueness and pervasive norm collision across most of its substantive areas" ${ }^{\prime \prime}$-resolution ultimately lies most frequently in the application of proportionality.

\section{Decline of Direct Effect and other Rules of Reliance as a Locus of Discretion in Internal Case Law}

The capability for individuals to rely on provisions of the EU Treaty against their Member State in domestic courts, so called vertical direct effect, first emerged in the van Gend en Loos case. ${ }^{62}$ Provided the relevant provision is clear, precise, and unconditional the Member State court must apply EU law and disapply conflicting national law. ${ }^{63}$ In Van Gend en Loos, the Court stated the relevant provision was "ideally adapted to produce direct effects," 64 and the criteria has been liberally applied to less ideal provisions since. For instance, free movement of workers "entail[s] the right [to accept offers of employment actually made ${ }^{65}$ in another Member State], subject to limitations justified on grounds of public policy, public security, or public health." ${ }^{66}$ However, such

\footnotetext{
${ }^{58}$ See MENDEZ, supra note 4 (concerning the Court's tendency to limit Member State action more greatly than EU legislative action)

${ }^{59}$ Notwithstanding the weaker consequence of interpretation of EU legislation in light of non-directly effective international agreements and continued liability at international level.

${ }^{60}$ See Ghazaryan, supra note 24 , at 64-74.

${ }^{61} \mathrm{BECK}$, supra note 1 , at 438.

${ }^{62}$ See ECJ, Case C-26/62, Van Gend en Loos v. Administratie der Belastingen, ECLI:EU:C:1963:1 (Feb. 5, 1963), http://curia. europa.eu/juris/liste.jsf?language $=$ en $\&$ num $=\mathrm{C}-26 / 62$.

${ }^{63}$ ECJ, Case C-106/77, Amministrazione delle Finanze dello Stato v. Simmenthal, ECLI:EU:C:1978:49 (Mar. 9, 1978), para. 24, http://curia.europa.eu/juris/liste.jsf?language=en\&num=C-106/77.

${ }^{64}$ van Gend en Loos, Case C-26/62 at 13.

${ }^{65}$ The Court expanded the provision to allow jobseekers access to other Member States as "a strict interpretation of [Article 45(3) TFEU] would . . . make that provision ineffective.” ECJ, Case C-292/89, Antonissen, ECLI:EU:C:1991:80 (Feb. 26, 1991), para 12, http://curia.europa.eu/juris/liste.jsf?language=en\&num=C-292/89.

${ }^{66}$ Consolidated Version of the Treaty on the Functioning of the European Union art. 45(3), May 9, 2008, 2008 O.J. (C 115) [hereinafter TFEU].
} 
limitations are "subject to judicial control [at EU level]"67 and therefore provisions with such conditionality can have direct effect. ${ }^{68}$ Craig and de Búrca note that " $[t]$ he idea that direct effect could apply even where the Member States possessed discretion ... represented a significant juridical shift in thinking about direct effect." ${ }^{\prime 9}$

Similarly, the Court's focus on negative obligation in Van Gend en Loos emerged as being nondispositive in Lütticke. $^{70}$ Here a positive obligation under The Treaty of Rome (EEC) Article 95 to repeal or amend discriminatory rules on taxation was considered "complete [and] legally perfect" ${ }^{\prime 11}$ and therefore capable of having direct effect. The case Defrenne v. Sabena (No. 2$)^{72}$ marked a relaxation of the "clear, precise and unconditional" criteria. ${ }^{73}$ The case concerned Article 119 of the EEC Treaty which provided for the "principle that men and women should receive equal pay for equal work." Advocate General Trabucchi conceded that the "form of words used ... may seem too vague and the meaning of the word 'principle' itself not to be very specific" but asserted that "the purpose of the rule is nevertheless clear." 74 The Court conceded that where discretion was "indirect and disguised, ... entire branches of industry and even of the economic system as a whole" would need to be addressed and therefore required legislative measures. ${ }^{75}$ However, in this case discrimination was direct and overt, meaning direct effect could be found. Scholars have noted the novelty in the fact that the provision "simultaneously [had] and did not have direct effect." ${ }^{76}$ The concept of direct effect has also expanded to include directives, ${ }^{77}$ and even unwritten general principles of EU law may be directly effective. ${ }^{78}$

Ultimately, there is the sense that "[d]irect effect is nothing but the ordinary state of [EU] law,"79 and it will be found wherever possible. Moreover, other rules governing reliance on EU law are equally liberal: First, Article 258 TFEU essentially presumes the Commission's capacity to rely on the Treaty and any rules relating to it in order to challenge Member State action. Member States are empowered equally, as against one another, through Article 259 TFEU.

Second, Article 263 TFEU provides a mechanism of direct judicial review before the CJEU. In analyzing "the validity and interpretation of acts of the institutions, bodies, offices, or agencies of the Union," 80 the Court applies the Treaty and rules emanating from it, including general

\footnotetext{
${ }^{67}$ ECJ, Case C-41/74, Van Duyn v. Home Office, ECLI:EU:C:1974:133 (Dec. 4, 1974), para 7, http://curia.europa.eu/juris/ liste.jsf?language $=\mathrm{en} \&$ num $=\mathrm{C}-41 / 74$.

${ }^{68}$ See ECJ, Case C-2/74, Reyners v. Belgian State, ECLI:EU:C:1974:68 (June 21, 1974), http://curia.europa.eu/juris/liste.jsf? language $=$ en $\&$ num $=\mathrm{C}-2 / 74$.

${ }^{69}$ Paul Craig \& Gráinne de Búrca, EU law: Text, Cases and Materials 190 (6th ed. 2015).

${ }^{70}$ ECJ, Case C-48/65, Lütticke v. Comm'n of the EEC, ECLI:EU:C:1966:8 (Mar. 1, 1966), http://curia.europa.eu/juris/liste. jsf?language $=$ en $\&$ num $=\mathrm{C}-48 / 65$.

${ }^{71} \mathrm{Id}$. at 210 .

${ }^{72}$ ECJ, Case C-43/75, Defrenne v. Sabena, ECLI:EU:C:1976:56 (Apr. 8, 1976), http://curia.europa.eu/juris/liste.jsf? language $=$ en $\&$ num $=\mathrm{C}-43 / 75$.

${ }^{73}$ Juha Raitio, The Principle of Legal Certainty in EC Law 353 (2003); Robert SChÜtze, European Union Law 85 (2015); CRAIG \& DE BúRCA, supra note 69, at 192.

${ }^{74}$ Opinion of Advocate General Trabucchi at 486, ECJ, Case C-43/75, Defrenne v. Sabena, ECLI:EU:C:1976:39 (Mar. 10, 1976), http://curia.europa.eu/juris/liste.jsf?language $=$ en\&num $=\mathrm{C}-43 / 75$.

${ }^{75}$ Defrenne v. Sabena, Case C-43/75 at paras. $18-19$.

${ }^{76}$ Sionaidh Douglas-Scott, Constitutional Law of the European Union 287 (2002). See also SchütZe, supra note 73 , at 85 .

${ }^{77}$ Van Duyn v. Home Office, Case C-41/74 at 1337.

${ }^{78}$ ECJ, Case C-260/89, Elliniki Radiophonia Tileorassi AE v. Dimotiki Etairia Pliroforissis, ECLI:EU:C:1991:254 (June 18, 1991), para 24, http://curia.europa.eu/juris/liste.jsf?language=en\&num=C-260/89.

${ }^{79}$ Pierre Pescatore, The Doctrine of Direct Effect: An Infant Disease of Community Law, 8 Eur. L. REv. 155, 177 (1983). See also Douglas-Scott, supra note 76, at 287; Athony ARnull, The European Union and ITs Court of Justice 157-79 (2d ed. 2006); Bruno de Witte, Direct Effect, Primacy and the Nature of the Legal Order, in THE EvoluTION OF EU LAW 334 (Paul Craig \& Gráinne de Búrca eds., 2d ed. 2011); and SCHÜTZE, supra note 73, at 87.

${ }^{80}$ TFEU art. $267(1)(\mathrm{b})$.
} 
principles, ${ }^{81}$ regardless of whether they have direct effect. ${ }^{82}$ Controversy regarding limited standing for EU institutions under Article 263 TFEU has now been addressed, meaning that they, along with Member States, may challenge EU legislation without questions of direct effect arising. Private individuals must demonstrate that the act is of direct and individual concern to them, with the interpretation of this criteria being narrow. ${ }^{83}$ Minor changes in the language of the provision in the Lisbon Treaty do not appear to have significantly affected this. ${ }^{84}$ However, if an individual does not fulfil the restrictive criteria of Article 263 TFEU they may proceed through the preliminary rulings procedure.

Third, under Article 267 TFEU, preliminary rulings procedure, if the matter concerns the validity of EU legislation the national court's question, it will prompt the CJEU to answer and to invalidate the legislation should this be required, regardless of direct effect. ${ }^{85}$

In all the instances above, the question as to whether a specific provision has direct effect is not enquired into: For Articles 258, 259, 263, and this aspect of Article 267 TFEU. However, under Article 267 TFEU, cases brought by individuals against Member States and private individuals will require direct effect of the relevant provision; otherwise the provision may only be useful in the more limited capacity of interpreting another EU and/or national law provision. ${ }^{86}$ Although, as noted above, the test for direct effect is itself generous.

The presumption, where relevant, of direct effect of EU legal provisions, combined with other rules which permit reliance creates a large opening, catches and then funnels cases through to the proportionality stage. It is submitted that proportionality-not direct effect-is the primary locus of the Court's discretion in internal case law. The impact and practical application of this can now be considered.

\section{Corresponding Rise of Proportionality as a Locus of Discretion in Internal Case Law}

With direct effect and other related rules invariably allowing reliance on EU law provisions, cases must then progress to consider their application. While EU law features a hierarchy in which we identify the EU Treaty as sitting above secondary legislation and secondary legislation above national law, ${ }^{87}$ it is submitted that this hierarchy is not especially informative regarding the resolution of most cases. Instead, the normative interest-pursued at any level of the hierarchy-is postulated at the EU treaty level, where multiple norms conflict and must be resolved through proportionality.

\footnotetext{
${ }^{81}$ See TRIDIMAS, supra note 2 , at 36.

${ }^{82}$ Morten Broberg \& Niels Fenger, Preliminary References to the European Court of Justice 213-22 (2010).

${ }^{83}$ For the general approach, see ECJ, Case C-25/62, Plaumann \& Co. v. Comm'n, ECLI:EU:C:1963:17 (July 15, 1963), http:// curia.europa.eu/juris/liste.jsf?language $=\mathrm{en} \&$ num $=\mathrm{C}-25 / 62$. But see F. Jacobs, Access by Individuals to Judicial Review in EU

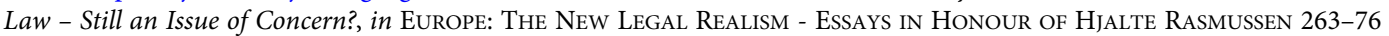
(H. Koch et al. eds., 2010), who discusses having previously advocated a broader interpretation in his role as Advocate General in ECJ, Case C-50/00 P, Unión de Pequeños Agricultores v. Council, ECLI:EU:C:2002:462 (July 25, 2002), http://curia.europa. $\mathrm{eu} / \mathrm{juris} /$ liste.jsf?language $=\mathrm{en} \&$ num $=\mathrm{C}-50 / 00$, which was followed by a similar approach in the General Court but rejected on appeal by the Court of Justice in ECJ, Case C-263/02 P, Comm’n v. Jégo-Quéré, ECLI:EU:C:2004:210 (Apr. 1, 2004), http:// curia.europa.eu/juris/liste.jsf?language $=$ en \&num $=\mathrm{C}-263 / 02$.

${ }^{84}$ ECJ, Case C-583/11 P, Inuit Tapiriit Kanatami and Others v. Parliament and Council, ECLI:EU:C:2013:625 (Oct. 3, 2013), paras. 55, 70, http://curia.europa.eu/juris/liste.jsf?language=en\&num=C-583/11. See also Carl Fredrik Bergström, Defending Restricted Standing for Individuals to Bring Direct Actions Against “Legislative” Measures, 10 EuR. Const. L. REV. 481 (2014).

${ }^{85}$ For this reason, it is said not to be between parties stricto sensu. See BROBERG \& FENGER, supra note 82, at 351. A limitation is that the question must be relevant for the national court to decide the case before it. See ECJ, Case C-104/79, Foglia v. Novello, ECLI:EU:C:1980:73 (Mar. 11, 1980), paras. 9-13, http://curia.europa.eu/juris/liste.jsf?language=en\&num=C-104/79.

${ }^{86}$ So-called indirect effect.

${ }^{87}$ See, e.g., Allen Rosas \& Lorna Armati, EU Constitutional Law: An Introduction 42 (2010).
} 
Proportionality arises in challenges to EU legislation and Member State action, essentially allowing defense of such actions through, in the case of the former, pursuit of another justified goal and, in the latter, recourse to derogations within the Treaty and those developed within the case law. The application of the proportionality test is noted to differ significantly depending upon whether EU or Member State action is challenged. The Court's approach and presentation of relevant steps within proportionality analyses are also not consistently presented. ${ }^{88}$

Nonetheless, the common steps for the Court in proportionality analyses are inquiries as to ${ }^{89}$ :

i. Whether the aim is recognized as legitimate by EU law.

ii. Whether the measure was suitable to achieve the desired end.

iii. Whether it was necessary to achieve the desired end.

iv. Whether the burden was excessive in relation to the objective sought to be achieved, proportionality stricto sensu.

It can be seen through this that proportionality requires, or at least facilitates, engagement with the facts and circumstances of a given case in a concrete way.

\section{Proportionality Applied to EU Action}

As hinted at above, a key modification to the proportionality test comes where EU secondary legislation is reviewed, as it often need not solely be manifestly disproportionate, or inappropriate, whereas Member State action should typically adopt the least restrictive means available. ${ }^{90}$ The distinction results in deference to the EU legislature where it is exercising discretion, though Member State action is subject to more intense review. ${ }^{91}$

The consequence of a lighter touch review of EU secondary legislation, as compared to intrusive analysis of Member State measures, is that case law reviewing EU action will also be less helpful in informing participants of the current normative state of EU law for this or future cases. ${ }^{92}$ Nonetheless, "the Community legislature is obliged to base its choice on objective criteria appropriate to the aim pursued by the legislation in question," including consideration of all facts and technical and scientific data available. ${ }^{93}$ All interests involved must be considered, and "the Community legislature's exercise of its discretion must not produce results that are manifestly less appropriate than those that would be produced by other measures that were also suitable for those objectives." ${ }^{4}$ This means that both the outcome and the procedure are subject to review.

\footnotetext{
${ }^{88}$ Wolf Sauter, Proportionality in EU Law: A Balancing Act?, 15 CAmbridge Y.B. EUR. STUD. 439, 448 (2013).

${ }^{89}$ See in combination, ECJ, Case C-55/94, Gebhard v. Consiglio dell'Ordine degli Avvocati e Procuratori di Milano, ECLI: EU:C:1995:411 (Nov. 30, 1995), para 37, http://curia.europa.eu/juris/liste.jsf?language=en\&num=C-55/94, and ECJ, Case C-110/05, Comm'n v. Italy, ECLI:EU:C:2009:66 (Feb. 10, 2009), para 59, http://curia.europa.eu/juris/liste.jsf?language= en\&num=C-110/05, and ECJ, Case C-112/00, Schmidberger, ECLI:EU:C:2003:333 (June 12, 2003), para 79, http://curia. europa.eu/juris/liste.jsf?language $=$ en $\&$ num $=\mathrm{C}-112 / 00$.

${ }^{90} \mathrm{~A}$ recent exception to this came in a line of case law showing tolerance of Member States adopting "easily managed and supervised" measures even if they were not the least restrictive means available. See, e.g., Commission v. Italy, Case C-110/05; ECJ, Case C-142/05, Åklagaren v. Mickelsson and Roos, ECLI:EU:C:2009:336 (June 4, 2009), para. 36, http://curia.europa.eu/ juris/liste.jsf?language=en\&num=C-142/05; ECJ, Case C-137/09, Josemans, ECLI:EU:C:2010:774 (Dec. 16, 2010), para. 82, http://curia.europa.eu/juris/liste.jsf?language=en\&num=C-142/05; and ECJ, Case C-512/13, Sopora, ECLI:EU:C:2015:108 (Feb. 24, 2015), para 33, http://curia.europa.eu/juris/liste.jsf?language=en\&num=C-512/13.

${ }^{91}$ See, e.g., BECK, supra note 1, at 422; Sybe A. DE VRIES, Tensions Within the InTERnal Market: The Functioning of the Internal Market and the Development of Horizontal Flanking Policies 16 (2006); Craig \& de Búrca, supra note 69 , at 532 .

${ }^{92}$ Sauter, supra note 88 , at $464-65$.

${ }^{93}$ ECJ, Case C-127/07, Société Arcelor Atlantique et Lorraine and Others v. Premier Minister, ECLI:EU:C:2008:728 (Dec. 16, 2008), para. 58, http://curia.europa.eu/juris/liste.jsf?language=en\&num=C-127/07.

${ }^{94} I d$. at para. 59.
} 
A further variation arises within proportionality review of EU action based on the nature of the conflicting rights. It is recognized that where a fundamental right is at stake, rather than a discretionary policy choice, the review of EU legislative action will be based on protecting the substance of the relevant right, and for this reason can be more intrusive. ${ }^{95}$ Proportionality and the nature of fundamental rights is developed further below. However, it should be noted that fundamental rights are readily balanced against other interests in review of both EU and Member State action.

\section{Proportionality Applied to Member State Action}

As stated at the introduction, proportionality is relevant in most areas of EU law. However, consideration of internal market case law is particularly helpful in identifying the normatively relative-less hierarchical — nature of EU law, as other norms are often measured against the four fundamental freedoms. ${ }^{96}$ Another notable point is that, in this case law, these "other" norms manifest themselves in national rules creating barriers to free movement, and the hierarchical place of national law - at the very bottom - does not preclude their normative weight as interests recognized as being of importance in EU law. Once recognized as such, provided the measure was appropriate and necessary, the Court can consider whether the restriction on trade, or another norm, was excessive in relation to the objective sought to be achieved-proportionality stricto sensu. Even where the Court does not balance norms against one another stricto sensu, which it is sometimes reluctant to do unless prompted, it is recognized that the relevant norms also affect the intrusiveness of tests of appropriateness and necessity. ${ }^{97}$ For this reason, the term "balance" is used liberally by scholars, and this is also the case here.

A snapshot of case law, therefore, reveals that, inter alia, protection of health can be more important than free movement of goods, ${ }^{98}$ as can public morality. ${ }^{99}$ Of course, these feature as express derogations in Article 36 TFEU, but environmental protection, ${ }^{100}$ fundamental rights, ${ }^{101}$ and consumer protection ${ }^{102}$ have the capacity to prevail similarly. The protection of norms beyond the closed-list of Article 36 TFEU illustrates the Court's inclination to entertain clashes between norms, even when previous case law would have implied that this was not possible. ${ }^{103}$ The Court's inclination to balance is strong, and it is not only the free movement norms-or "trade" norms - against which others are balanced, this is just the most prominent area of practice. By way of brief example, fundamental rights are frequently balanced against the public interest ${ }^{104}$-or

\footnotetext{
${ }^{95}$ Paul Craig, EU Administrative Law 656-63 (3d ed. 2018).

${ }^{96}$ Loïc Azoulai, The European Court of Justice and the Duty to Respect Sensitive National Interests, in JUDICIAL ACTIVISM AT The European Court of Justice 168 (Mark Dawson, Bruno de Witte \& Elise Muir eds., 2013).

${ }^{97}$ See Harbo, supra note 13, at 172; CRAIG, supra note 95, at 653-54.

${ }^{98}$ ECJ, Case C-24/00, Commission v. France, ECLI:EU:C:2004:70 (Feb. 5, 2004), http://curia.europa.eu/juris/liste.jsf? language $=$ en $\&$ num $=\mathrm{C}-24 / 00$.

${ }^{99}$ ECJ, Case C-34/79, Regina v. Henn and Darby, ECLI:EU:C:1979:295 (Dec. 14, 1979), http://curia.europa.eu/juris/liste.jsf? language $=$ en $\&$ num $=\mathrm{C}-34 / 79$.

${ }^{100}$ ECJ, Case C-379/98, PreussenElektra v. Schleswag AG, ECLI:EU:C:2001:160 (Mar. 13, 2001), http://curia.europa.eu/ juris/liste.jsf?language $=$ en $\&$ num $=\mathrm{C}-379 / 98$.

${ }^{101}$ See, e.g., Schmidberger, Case C-112/00.

${ }^{102}$ See, e.g., ECJ, Case C-313/94, Graffione v. Ditta Fransa, ECLI:EU:C:1996:450 (Nov. 26, 1996), http://curia.europa.eu/ juris/liste.jsf?language $=$ en\&num $=\mathrm{C}-313 / 94$.

${ }^{103}$ For instance, in PreussenElektra, Case C-379/98, the national measure appeared discriminatory but was still justified as a mandatory requirement (environmental protection), which in the Court's case law had hitherto only been available only to non-discriminatory measures.

${ }^{104}$ See, e.g., ECJ, Case C-4/73, Nold KG v. Comm'n, ECLI:EU:C:1975:114 (Sep. 24, 1975), para. 14, http://curia.europa.eu/ juris/liste.jsf?language $=$ en\&num $=\mathrm{C}-4 / 73$; ECJ, Case C-11/70, Internationale Handelsgesellschaft, ECLI:EU:C:1970:114 (Dec. 17, 1970), para. 24, http://curia.europa.eu/juris/liste.jsf?language=en\&num=C-11/70; ECJ, Case C-44/79, Hauer v. Land Rheinland-Pfalz, ECLI:EU:C:1979:290 (Dec. 13, 1979), para. 23, http://curia.europa.eu/juris/liste.jsf?language=en\&num= C-44/79.
} 
even public health $-{ }^{105}$ and equal treatment has been balanced against environmental protection. ${ }^{106}$ The necessity of balancing is inherent in the postulation of multiple norms at the same level_EU treaty and general principle — which means that the Court frequently must "strike a "balance" between competing "integrated" values. ${ }^{107}$ This reality marks the decline of hierarchy and the corresponding rise of proportionality in internal case law.

This also affects the nature of the norms themselves and, by extension, the EU legal system in which norms are accorded relative-rather than intrinsic-weight. Accordingly, restrictions to fundamental rights must "not constitute, with regard to the aim pursued, disproportionate and unreasonable interference undermining the very substance of that right." 108 This means that such rights are not "absolute prerogatives," 109 but may have an "essence" or "very substance," which suggests a hardening at their center, although the precise scope of this varies and is unclear. ${ }^{110}$ This flexibility is perhaps appropriate given the proliferation of fundamental rightssome of vital importance, but some covering even "the most mundane matters." 111 Ultimately, albeit with stricter review from the Court, fundamental rights have a "relational character"112 and the Court readily balances them against other norms, ${ }^{113}$ essentially seeking a "fair balance between them." 114 Thus, "[t]here is no distinction and hence no hierarchical relationship being posited by the European Court between the basic human rights ... and the free market rights." 115 Instead, human rights are subject to "the interpretative practice of balancing to reconcile the competing rights and interests." 116

Similarly, concerning trade liberalization and consumer protection, Weatherill observes "many delicate cases" in which "[j]udges must decide which interest prevails - and why,"117 with proportionality analyses facilitating the "sensitive task of adjudication without any intricate set of guidance or hierarchy mapped by the founding Treaties." 118 Ultimately, "the Court makes a radical choice on a case-by-case basis ... radical in the sense that there are no overarching criteria that provide a rational basis for preferring one value to another." ${ }^{119}$ Properly applied, however, it has also been suggested that "[b]alancing offers the best possible predictability in a flexible

\footnotetext{
${ }^{105}$ ECJ, Case C-544/10, Deutsches Weintor eG v. Land Rheinland-Pfalz, ECLI:EU:C:2012:526 (Sep. 6, 2012), http://curia. europa.eu/juris/liste.jsf?language $=$ en\&num $=\mathrm{C}-544 / 10$.

${ }^{106}$ Société Arcelor Atlantique et Lorraine and Others, Case C-127/07.

${ }^{107}$ Rainer Nickel, From Integration Through Law to Integration Through Conflict, in 'INTEgRATION THROUGH LAW' Revisited: The Making of The European Polity 121 (Daniel Augenstein ed., 2012).

${ }^{108}$ See, e.g., ECJ, Case C-292/97, Karlsson and Others, ECLI:EU:C:2000:202 (Apr. 13, 2000), para. 45, http://curia.europa.eu/ juris/liste.jsf?language=en\&num=C-292/97; ECJ, Case C-280/93, Ger. v. Council, ECLI:EU:C:1994:367 (Oct. 5, 1994), para. 73, http://curia.europa.eu/juris/liste.jsf?language=en\&num=C-280/93; ECJ, Case C-265/87, Schräder v. Hauptzollamt Gronau, ECLI:EU:C:1989:303 (July 11, 1989), para. 15, http://curia.europa.eu/juris/liste.jsf?language=en\&num=C-265/87; ECJ, Case C-5/88, Wachauf v. Bundesamt für Ernährung und Forstwirtschaft, ECLI:EU:C:1989:321 (July 13, 1989), para 18, http://curia.europa.eu/juris/liste.jsf?language=en\&num=C-5/88.

${ }^{109}$ Steve Peers, Taking Rights Away? Limitations and Derogations, in The EU Charter of Fundamental Rights: Politics, LaW AND Policy 143 (Steve Peers \& Angela Ward eds., 2004).

${ }^{110}$ Paul Craig, EU Administrative Law 680 (1st ed. 2006).

${ }^{111}$ Mattias Kumm, Internationale Handelsgesellschaft, Nold and the New Human Rights Paradigm, in THE PAST AND Future of EU Law: The Classics of EU Law Revisited on the 50Th Anniversary of the Rome Treaty 107 (Miguel Poiares Maduro \& Loïc Azoulai eds., 2010). See particularly Deutsches Weintor eG, Case C-544/10.

${ }^{112}$ Marton Varju, European Union Human Rights Law: The Dynamics of Interpretation and Context (Edward Elgar 2014) 263.

${ }^{113}$ See BECK, supra note 1 , at 178 .

${ }^{114}$ See, e.g., Deutsches Weintor eG, Case C-544/10, at para. 47.

${ }^{115} J a s o n$ Coppel and Aidan O’Neill, 'The European Court of Justice: taking rights seriously?' (1992) 29(4) Common Market Law Review 669 cited in Sionaidh Douglas-Scott, Constitutional Law of the European Union (Pearson 2002) 457.

${ }^{116}$ Marton Varju, European Union Human Rights Law: The Dynamics of Interpretation and ConteXt 264 (2014).

${ }^{117}$ Stephen Weatherill, EU Consumer Law and Policy 308 (2d ed. 2014).

${ }^{118} I d$.

${ }^{119}$ See BECK, supra note 1 , at 178.
} 
jurisdiction. [As] [a]ll conflicting interests are taken into account clearly and openly in every single case." $" 20$

Schmidberger - concerning protests limiting free movement of goods - is a helpful example of this. There, the Court stated that "the interests involved must be weighed having regard to all the circumstances of the case in order to determine whether a fair balance was struck between those interests." 121 In comparing the protest in Schmidberger to the protest in Spanish Strawberries ${ }^{122}$ which was found to have "serious and repeated disruptions to public order" 123 — the Court was able to indicate the factors that contributed to the Schmidberger protest being justified, identifying the "various administrative and supporting measures [that] were taken by the competent authorities in order to limit as far as possible the disruption to road traffic." 124

\section{Reflections on Proportionality Internally}

In spite of many variables - based on actor, subject matter, nature of right, and changing weight of norm-harsh critics of proportionality within the EU remain few in number. ${ }^{125}$ Instead, there is recognition by most that proportionality can mitigate the harshness of supremacy coupled with direct effect from the Member State point of view, ${ }^{126}$ in addition to providing meaningful review of EU action. ${ }^{127}$ It can also be seen that even where loosely or partially followed, the common steps of proportionality will prompt the Court-in what is undeniably a complex and developing legal system - to at least be somewhat forthcoming concerning its reasoning, and to engage with the facts and circumstances of the case in a concrete way.

With direct effect invariably granted - and often not being required ${ }^{128}$ — it is evident that discretion in internal case law manifests itself primarily through proportionality, that the EU legal order is emerging as non-hierarchical in practice, and that the Court has a key role in incrementally developing the relevant norms. ${ }^{129}$ These factors carry implications for external relations case law, as can now be explored.

\section{Emergence of Discretion by Means Other than Proportionality in External Relations Case Law Due to its Significant Absence \\ I. Inevitability of Discretion: Proportionality's Shadow in External Relations Case Law}

As noted at the introduction, proportionality analyses are very largely absent in external relations case law. ${ }^{130}$ Instead, there is the purport of a formalistic hierarchy, in which international law is mechanically applied in external relations case law in situations where it has direct effect. However, having had a prominent role in developing norms incrementally in internal

\footnotetext{
${ }^{120}$ Matthias Klatt \& Moritz Meister, The Constitutional Structure of Proportionality 32 (2012).

${ }^{121} I d$. at para. 81 .

${ }^{122}$ ECJ, Case C-265/95, Comm'n v. France, ECLI:EU:C:1997:595 (Dec. 9, 1997), http://curia.europa.eu/juris/liste.jsf? language $=$ en $\&$ num $=\mathrm{C}-265 / 95$.

${ }^{123} I d$. at para. 88.

${ }^{124} I d$. at para. 87

${ }^{125}$ But see Harbo, supra note 13 , at $158-85$.

${ }^{126}$ Sauter, supra note 88 , at 464 .

${ }^{127}$ CRAIG, supra note 95 , at 647.

${ }^{128}$ See, e.g., TFEU arts. $258,259,263,267$ when questioning the validity of EU legislation.

${ }^{129}$ Environmental protection is a notable example and causes scholars to question whether prominent EU environmental law case law from the 1980s would be decided similarly today. See Stuart Bell, Donald McGillivray \& Ole Pedersen, Environmental Law 225 (8th ed. 2013). See also Elina Paunio, Legal Certainty in Multilingual EU Law: Language, Discourse and Reasoning at the European Court of Justice 87-94 (2013).

${ }^{130}$ For exceptions, see infra, Section $\mathrm{D}(\mathrm{III})(3)$.
} 
case law, ${ }^{131}$ the following question remains: Is it to be expected that the Court will eschew the norms developed in its internal case law when applying international law in external relations cases?

The Court's refusal to permit its members to sit on any newly created international court in Opinion $1 / 91^{132}$ was based on its view that "it will be very difficult, if not impossible, for those judges, when sitting in the Court of Justice, to tackle questions with completely open minds where they have taken part in determining those questions as members of the EEA Court."133 However, the converse must hold, and even more strongly. The Court cannot be expected to disavow its normative conceptions and mechanically apply international provisions to invalidate EU law. Indeed, the idea that courts have the capacity to "split roles," so that "any time a domestic court deals with a conflict of law question, it acts qua an international body," 134 has recently been described as "overly optimistic"135 and "shaky."136

The external relations case law analyzed below is strong evidence that the Court is not able to divide its internal function from its role in applying international law. Instead, modified rules of reliance and application seek to alleviate the absence of proportionality in external relations case law so as to protect EU norms from international law. Setting aside the fact that "it is by no means clear that a neatly defined hierarchy is always the best way of resolving conflicts within a legal system," 137 it is true that a strict hierarchy, mechanically enforced, would give rise to greater legal certainty than would balancing competing norms through proportionality. ${ }^{138}$ However, as we shall now see, this is no longer the case in external relations case law.

Unsurprisingly, normative concerns have permeated the strict hierarchy. We will see that the direct effect test is modified relentlessly, autonomy is claimed-on unclear bases and with varied effects, and interpretative methods emerge as questionable concerning international treaty and customary international law (CIL). This though, it will be seen, falls a long way short of proportionality, in which "[a]ll conflicting interests are taken into account clearly and openly in every single case." ${ }^{139}$ Instead, we have the worst of both worlds: Neither a strict hierarchy nor proportionality, but rather discretion exercised covertly through supposedly mechanical rules. The result is a lack of nuanced balance and loss of legal certainty.

Whilst proportionality would not overcome the reality that domestic judges, either through issues of competence, confidence, or allegiance, are more likely to favor domestic methods or viewpoints, the benefits of its application to this area would be significant. ${ }^{140}$ Following the analysis on external relations case law we will be better placed to understand the modest means by which proportionality could be deployed. Indeed, in some cases it already has been. It should also be mentioned that the proposal to deploy proportionality in external relations case law is not limited to those agreements which have direct effect currently. Instead, it would be anticipated that access to proportionality for the Court will lessen the need for narrow distinctions within direct

\footnotetext{
${ }^{131}$ On the collaborative development of norms by the Court and legislature, see Phil Syrpis, Theorising the Relationship Between the Judiciary and the Legislature in the EU Internal Market, in THE JUdiciary, THE LEGISLATURE AND THE EU INTERNAL MARKET (Phil Syrpis ed., 2012).

${ }^{132}$ Opinion 1/91, Re Agreement on the European Economic Area, 1994 ECR I-6079.

${ }^{133} \mathrm{Id}$. at paras. $51-52$.

${ }^{134}$ Antonio Cassese, Remarks on Scelle's Theory of "Role Splitting" (dédoublement fonctionnel) in International Law, 1 EUR. J. INT'L L. 210, 213 (1990).

${ }^{135}$ Halberstam, supra note 38 , at 197.

${ }^{136}$ See NollkaEmper, supra note 27, at 47. See also Aust, Rodiles \& Staubach, supra note 38, at 111.

${ }^{137}$ LON L. Fuller, The Morality of Law 112 (1969).

${ }^{138}$ Compare, for example, the narrow, hierarchical, mechanical approach in MAX WEBER, ECONOMY AND SOCIETY 886 (Guenther Ross \& Claus Wittich eds., 1978), with the Herculean, all-encompassing, but less certain approach in RoNALD DWORKIN, LAW's EMPIRE, 245 (1986).

${ }^{139}$ KLATT \& MEISTER, supra note 120 , at 32.

${ }^{140}$ See infra, Section $\mathrm{D}(\mathrm{V})$.
} 
effect, thus mirroring more fully the internal approach with a more ready acceptance of direct effect where needed and subsequent application of proportionality. ${ }^{141}$

\section{Manifestations of Discretion in External Relations Case Law I: Modifications to Direct Effect-Related Rules in the Absence of Proportionality}

\section{Discretion Through Wider Application of Direct Effect Tests in External Relations Case Law}

In spite of distinguishing EU law as a "new legal order of international law" uniquely capable of direct effect in Van Gend en Loos, in International Fruit, ${ }^{142}$ the Court confirmed that provisions of "old" international law could also have direct effect in the EU. Though relatively receptive of international law, this case already marked a divergence from the equivalent scope of application of internal direct effect. As above, we have seen that in Article 267 TFEU cases calling into question validity of EU legislation, direct effect of relevant rules is not required, whereas in International Fruit it was.

However, in Haegeman II, ${ }^{143}$ the Court reviewed the Commission's imposition of a "countervailing charge" on the basis of an Association Agreement with Greece. The case was also an Article 267 TFEU referral, and the Court utilized for the first time the oft-cited phrase that " $\mathrm{t}]$ he provisions of [an international] agreement, from the coming into force thereof, form an integral part of Community law." ${ }^{144}$ This expression was particularly fitting as the Court did not enquire into direct effect at all, which matched with the internal approach. However, the case has become an anomaly, and direct effect appears to be required before international law can be relied upon to invalidate EU legislation in Article 267 TFEU actions.

It also emerged that even privileged applicants under Article 263 TFEU-such as the Member States - cannot rely on international agreements to which the EU is party to challenge EU legislative action, unless that provision is directly effective. ${ }^{145}$ In this light, it is worthy of mention that the Commission's capacity to rely on international agreements to which the EU is party in 258 TFEU enforcement actions against Member States is uncircumscribed-matching the approach in internal case law. ${ }^{146}$ This gives rise to some asymmetry.

However, in Biotechnological Inventions, an Article 263 TFEU case, the Court stated that ${ }^{147}$ :

Even if ... the [Convention on Biological Diversity] contains provisions which do not have direct effect ... that fact does not preclude review by the courts of compliance with the obligations incumbent on the Community as a party to that agreement.

This matches with the internal approach in which challenges to EU action are readily entertained. Eeckhout has speculated that the reason for departure from previous external relations case law may be "that the Court felt embarrassed by the incapacity of the Member States to seek judicial review [of EU legislation] on grounds of violation of certain [international] agreements."148 However, Eeckhout forewarned that this approach may not continue, and Pavoni notes that

\footnotetext{
${ }^{141}$ This also reflects the suggestions of Eeckhout and Mendez concerning reform of external relations case law, considered above, supra Section B(IV).

${ }^{142}$ See ECJ, Joined Cases C-21 to 24/72, International Fruit Company and Others v. Produktschap voor Groenten en Fruit, ECLI:EU:C:1972:115 (Dec. 12, 1972), http://curia.europa.eu/juris/liste.jsf?language=en\&num=C-21/72.

${ }^{143}$ Haegeman, Case C-181/73.

${ }^{144} I d$. at para. 5 .

${ }^{145}$ See, e.g., Germany v. Council, Case C-280/93; ECJ, Case C-149/96, Portugal v. Council, ECLI:EU:C:1999:574 (Nov. 23, 1999), http://curia.europa.eu/juris/liste.jsf?language=en\&num=C-149/96.

${ }^{146}$ ECJ, Case C-61/94, Comm'n v. Germany, ECLI:EU:C:1996:313 (Sep. 10, 1996), http://curia.europa.eu/juris/liste.jsf? language $=$ en $\&$ num $=\mathrm{C}-61 / 94$.

${ }^{147}$ ECJ, Case C-377/98, Netherlands v. Comm'n, ECLI:EU:C:2001:523 (Oct. 9, 2001), paras. 54-56, http://curia.europa.eu/ juris/liste.jsf?language $=$ en $\&$ num $=$ C-377/98.

${ }^{148}$ EeCKHOUT, supra note 53, at 297-98.
} 
"it appears that the Court of Justice is willing to duck the Biotech Patents decision, which has never been endorsed in its subsequent jurisprudence on external relations." ${ }^{449}$ And, in spite of encouragement by Advocate General Jääskinen, the Court was not inclined to utilize it more recently. ${ }^{150}$

The above demonstrates oscillations concerning the requirement for direct effect externally in Article 263 and 267 TFEU cases; a requirement which is not present in internal case law. Accordingly, direct effect, at the Court's discretion, has a potentially wider application than in internal case law. There are also significant oscillations in the application of the direct effect test itself externally, which will now be considered.

\section{Discretion Through Elusive Terms: Broad Scope and Logic/Spirit or Nature of Agreement In International Fruit, ${ }^{151}$ the Court stated that ${ }^{152}$ :}

Before invalidity can be relied upon before a national court, that provision of international law must also be capable of conferring rights on citizens of the Community which they can invoke before the courts.

The Court then explained that "the spirit, the general scheme and the terms of the general agreement must be considered" in order to answer this question. ${ }^{153}$ The words "spirit" or "nature" provide potentially elusive benchmarks, and therefore "the CJEU's discretion in applying these criteria is high and requires an amount of subjectivity." 154 Similar formulations have been used by the Court since. These tended not to utilize the conferral of rights criteria expressly, instead replacing it with analysis of the "wording and the purpose and nature" 155 of agreements, which is equally elusive.

It is well known that the Court's case law concerning, first, General Agreement on Tariffs and Trade (GATT), and second, World Trade Organization (WTO) agreements, resulted in the blanket exclusion of direct effect of these treaties based on their "broad scope and logic." 156 In International Fruit, the Court refused direct effect of GATT due to its flexible nature. The

\footnotetext{
${ }^{149}$ R. Pavoni, Controversial Aspects of the Interaction Between International and EU Law in Environmental Matters: Direct Effect and Member States' Unilateral Measures, in The External Environmental Policy of the European Union 351 (Elisa Morgera ed., 2012).

${ }^{150}$ Opinion of Advocate General Jääskinen at para. 10, ECJ, Joined Cases C-404 \& 405/12 P, Council and Comm'n v. Stichting Natuur en Milieu and Pesticide Action Network Europe, ECLI:EU:C:2014:309 (May 8, 2014), http://curia. europa.eu/juris/liste.jsf?language $=$ en\&num $=\mathrm{C}-404 / 12$.

${ }^{151}$ International Fruit Company, Joined Cases C-21 to 24/72.

${ }^{152} I d$. at para. 8 .

${ }^{153} I d$. at para. 20.

${ }^{154}$ Szilárd Gáspár-Szilágyi, EU International Agreements Through a US Lens: Different Methods of Interpretation, Tests and the Issue of "Rights", 39 EuR. L. REV. 601, 615 (2014).

${ }^{155}$ See ECJ, Case C-12/86, Demirel v. Stadt Schwäbisch Gmünd, ECLI:EU:C:1987:400 (Sep. 30, 1987), para 14, http://curia. europa.eu/juris/liste.jsf?language =en\&num=C-12/86. See also ECJ, Case C-213/03, Syndicat Professionnel Coordination des Pêcheurs de l'Etang de Berre et de la Region v. Électricité de France, ECLI:EU:C:2004:464 (July 15, 2004), para. 39, http://curia. europa.eu/juris/liste.jsf?language =en\&num=C-213/03; ECJ, Case C-171/01, Wählergruppe "Gemeinsam Zajedno/Birlikte Alternative und Grüne GewerkschafterInnen/UG", and Bundesminister für Wirtschaft und Arbeit and Others, ECLI:EU: C:2003:260 (May 8, 2003), para. 54, http://curia.europa.eu/juris/liste.jsf?language=en\&num=C-171/01.

${ }^{156}$ The debate over the merits of this position has been intense. For a defense of the jurisprudence of the Court, see, for example, S. Griller, Judicial Enforceability of WTO Law in the European Union: Annotation to Case C-149/96, Portugal v Council, 3 J. INT'L ECON. L. 441 (2000); Piet Eeckhout, Judicial Enforcement of WTO Law in the European Union - Some Further Reflections, 5 J. INT'L ECON. L. 91 (2002); MENDEZ, supra note 4, at 174-249. For criticism, see, for example, Ernst-Ulrich Petersmann, Can the EU's Disregard for "Strict Observance of International Law" (Article 3 TEU) Be Constitutionally Justified?, in TRADE AND COMPETITION LAW IN THE EU AND BEYOND (Inge Govaere, Reinhard Quick \& Marco Bronckers eds., 2011); Nikos Lavranos, The ECJ's Relationship with Other International Courts and Tribunals, in Europe: The New Legal Realism - Essays in Honour of HJalte Rasmussen (Henning Koch et al. eds., 2010).
} 
subsequent WTO agreement was viewed as carrying more concrete obligations. However, in Portuguese Textiles, the Court refused to accept that it could have direct effect. ${ }^{157}$ Whilst the Court accepted that the WTO agreement did "differ significantly . . . in particular by reason of the strengthening of the system of safeguards and the mechanism for resolving disputes." 158 It added immediately that "the system resulting from those agreements nevertheless accords considerable importance to negotiation between the parties." 159 The Court made reference, in passing, to the preamble and to annexes too, ${ }^{160}$ the former of which led the Court to focus on aspects of reciprocity. It noted that it was unlike agreements between the EU and other non-member countries "which introduce a certain asymmetry of obligations or create special relations of integration with the Community." 161 It also went on to observe that "some of the contracting parties, which are among the most important commercial partners of the community" had not considered the rules to be "applicable by their judicial organs when reviewing the legality of their rules of domestic law." 162

However, in Kupferberg, the Court broadly asserted that a "framework for consultations and negotiations between the parties inter se . . is not in itself sufficient to exclude all judicial application of it." ${ }^{163}$ This was because case concerned a Free Trade Agreement with Portugal, ${ }^{164}$ and may therefore be thought to be rather different from WTO law. Indeed, Eeckhout notes that concerning "direct effect of free-trade, co-operation, and association agreements the Court has never decided against direct effect on the basis of the structure and nature of the agreement as such." 65 Klabbers similarly observes of Kupferberg that "[d]irect effect within one of the parties' legal system but not within the other's would not, e.g., constitute a fatal lack of reciprocity." 166

Of course, the reality is that reciprocity is being used as an inconvenient proxy, enabling covert differentiation on the basis of the trading partner. But this creates confusion. Indeed, in Kupferberg itself, Advocate General Rozès, unlike the Court, thought that direct effect should not be granted as it would be to the Community's "disadvantage" where Portugal did not "guarantee that an individual may rely on the provision in Portugal on the same terms and with the same results." 167 Once more, discretion emerges.

\section{Discretion Through Selective Adherence to Binding Decisions of Bodies Established Under Agreements} The "remarkable phenomenon" 168 in which decisions of bodies established by international agreements could have direct effect was established in Sevince. ${ }^{169}$ This case concerned the EU-Turkey Association Agreement, ${ }^{170}$ which was found in Demirel not to have direct effect as it set out a

\footnotetext{
${ }^{157}$ Portugal v. Council, Case C-149/96.

${ }^{158} \mathrm{Id}$. at para. 47.

${ }^{159} \mathrm{Id}$. at para. 47.

${ }^{160} I d$. at para. 42 .

${ }^{161} I d$.

${ }^{162} I d$. at para. 44.

${ }^{163}$ ECJ, Case C-104/81, Hauptzollamt Mainz v. CA Kupferberg, ECLI:EU:C:1982:362 (Oct. 26, 1982), para. 20, http://curia. europa.eu/juris/liste.jsf?language $=$ en\&num $=\mathrm{C}-104 / 81$.

${ }^{164}$ Agreement Concluded on 22 July 1972 Between the European Economic Community and the Portuguese Republic, 1972 O.J. SPEC. ED. 167.

${ }^{165}$ EeCKHOUT, supra note 53, at 338.

${ }^{166}$ Jan Klabbers, International Law in Community Law: The Law and Politics of Direct Effect, 21 Y.B. EUR. L. 263,282 (2001).

${ }^{167}$ Opinion of Advocate General Rozès, Case C-104/81, Hauptzollamt Mainz v. CA Kupferberg (Oct. 26, 1982).

${ }^{168}$ Marc Maresceau, Bilateral Agreements Concluded by the European Community, 309 ColleCted Courses HaGUe ACAD. INT'L L. 125, 295 (2004).

${ }^{169}$ ECJ, Case C-192/89, S.Z. Sevince v. Staatssecretaris Van Justitie, ECLI:EU:C:1990:322 (Sept. 20, 1990), https://curia. europa.eu/juris/liste.jsf?language $=$ en $\&$ num $=\mathrm{C}-192 / 89$.

${ }^{170}$ Council Directive of December 29, 1964, Establishing an Association between the European Economic Community and Turkey, 1977 O.J. (L. 361) 29 (EC).
} 
"programme ... not sufficiently precise and unconditional to be capable of governing directly the free movement of workers." 171 However, in Demirel, the Court referred to Decision 1/80 of the Council of Association, which had been given "exclusive powers to lay down detailed rules" for the functioning of the agreement. ${ }^{172}$ The Decision was not relevant to the case at hand, but in referring to it, the Court implied that such Decisions would be determinative in future cases. In Sevince, the Court found that the programmatic nature of the EU-Turkey Association Agreement, ${ }^{173}$ which gave the Council of Association power to lay down detailed rules for its functioning, "does not prevent ... decisions ... which give effect in specific respects to the programmes envisaged ... from having direct effect." ${ }^{174}$ Accordingly, Decision 2/76 and 1/80 could have direct effect, a finding that was said to "merely lay emphasis on the obligation to implement in good faith an international Agreement." 175

The conditionality of WTO obligations will be recalled as being a central tenet in the precluding of direct effect in Portuguese Textiles. ${ }^{176}$ The WTO dispute settlement procedure's binding nature is also debated. ${ }^{177}$ Article 19 of the Dispute Settlement Understanding (DSU) says that the panel (DSB) or Appellate Body "shall recommend that a Member concerned bring the measure into conformity" in the case of a breach or that the relevant body "may suggest ways in which the Member could implement the recommendations." Article 22(2) DSU provides that in the event of non-compliance a "Member shall ... enter into negotiations with any party having invoked the dispute settlement procedures, with a view to developing mutually acceptable compensation." Article 21 DSU though speaks of "prompt compliance" being "essential" to the system. "Compensation [by the Member in breach] and suspension of other obligations [by Members harmed]" are considered to be "temporary" alternatives in the event of non-compliance and "neither compensation nor the suspension of concessions or other obligations is preferred to full implementation of a recommendation to bring a measure into conformity with the covered agreements." ${ }^{178}$ Article 3(7) DSU supports this further by stating that "compensation should be resorted to only if the immediate withdrawal of the measure is impracticable and as a temporary measure." Could this clear postulation of a hierarchical preference for compliance ${ }^{179}$ render a DSB or Panel recommendation directly effective in the EU legal system given the "good faith" in implementation of international law referred to in Sevince?

The Biret ${ }^{180}$ case appeared to leave the door open to such a possibility. ${ }^{181}$ A negative DSB finding was made in 1997 concerning the EU's banning of certain substances being administered to farm animals. ${ }^{182}$ Though the case was unsuccessful, the reasoning of the Court was very much

\footnotetext{
${ }^{171}$ ECJ, Case 12/86, Meryem Demirel v. Stadt Schwäbisch Gmünd, ECLI:EU:C:1987:400 (Sept. 30, 1987), para. 23, https:// curia.europa.eu/juris/liste.jsf?language $=$ en $\&$ jur $=\mathrm{C}, \mathrm{T}, \mathrm{F} \&$ num $=\mathrm{C}-12 / 86 \& \mathrm{td}=\mathrm{ALL}$.

${ }^{172}$ See Meryem Demirel, Case $12 / 86$ at para. 21.

${ }^{173}$ Council Directive of 29 December 1964, Establishing an Association between the European Economic Community and Turkey, 1977 O.J. (L. 361) 29 (EC).

${ }^{174}$ See Sevince, Case C-192/89 at para. 21.

${ }^{175} I d$. at para. 23.

${ }^{176}$ ECJ, Case C-149/96, Portugal v. Council, ECLI:EU:C:1999:574 (Nov. 23, 1999), http://curia.europa.eu/juris/liste.jsf? language $=$ en $\&$ num $=\mathrm{C}-149 / 96$.

${ }^{177}$ See Understanding on Rules and Procedures Governing the Settlement of Disputes, art. 1, Apr. 15, 1994, Marrakesh Agreement Establishing the World Trade Organization, Annex 2, 1869 U.N.T.S. 401 [hereinafter DSU]. For a close analysis of the WTO case law see Petros C. Mavroidis, Remedies in the WTO Legal System: Between a Rock and a Hard Place, 11(4) EUR. J. INT'L. L. 763 (2000).

${ }^{178}$ See DSU art. 22.

${ }^{179}$ Eeckhout suggests that, after a breach has been "authoritatively" found by the Dispute Settlement Body, there is "a violation of the DSU provisions requiring compliance" and that, "[a]ll this is quite serious." See Eeckhout, supra note 57, at 27.

${ }^{180}$ ECJ, Case C-93/02P, Biret International SA v. Council, ECLI:EU:C:2003:517, (Sept. 30, 2003), https://curia.europa.eu/ juris/liste.jsf?language $=$ en \&jur $=\mathrm{C}, \mathrm{T}, \mathrm{F} \&$ num $=\mathrm{c}-93 / 02 \& \mathrm{td}=\mathrm{ALL}$.

${ }^{181}$ Mario Mendez, The Impact of WTO Rulings in the Community Legal Order, 29 Eur. L. Rev. 517, 529 (2004); ANNE THEIS, International Trade Disputes and EU Liability 27 (2013).

${ }^{182}$ The substance ban included certain hormonal supplements and all substances having thyrostatic action.
} 
focused on the "timeline." As will be seen below, where the EU intends to implement WTO law, a review of secondary legislation on its basis can occur. ${ }^{183}$ However, because the relevant Union legislation was adopted "several years before" the WTO rules came into force, it was "not logically possible for them either to give rise to a specific obligation entered into under that agreement or to refer expressly to some of its provisions." 184 As to the breach of the DSB recommendation, the Court observed that a grace period had been provided until May 13, 1999. As the applicant's losses fell within this period, the Court found that the EU "cannot, on any view, have incurred liability." 185 Though the tone of the judgment could hardly be considered generous to the possible effects of WTO law before EU courts, by engaging with detailed claims rather than dismissing them in "broad logic," the question remained concerning the possible direct effect of WTO law after DSB or Appellate Body decisions. ${ }^{186}$

The Van Parys case followed. ${ }^{187}$ After a negative 1997 DSB finding on EU banana imports, the EU implemented a new Regulation ${ }^{188}$ "expressly" referring to the aim of bringing EU rules into compliance with the WTO system. ${ }^{189}$ This was found not to have been successful by the WTO in 1999, and the Court acknowledged that at that point the time limit had expired. ${ }^{190}$ Van Parys challenged the Regulation, but the combined considerations of expired time limit and possible Nakajima-type implementation principle ${ }^{191}$ were not sufficient for WTO rules to be relied upon.

The Court instead placed great emphasis on Article 22(2) DSU, allowing for negotiation over compensation. The Court did acknowledge that the main aim under Article 3(7) DSU was compliance, but also that there is anticipation of continued breach "where the immediate withdrawal of the measures is impracticable." 192 Though it is suggested that, at WTO level, "the exception [of impracticability] has become the rule," 193 the argument is at least engaged with. In Van Parys, there was no questioning at all of whether impracticability was present, let alone a reference to the fact that the relevant time period, even in the presence of impracticability, "should not exceed 15 months." 194 This was so in spite of the reference from the Belgian court being lodged in 2002, some three years after the negative WTO finding. The Court's refusal to acknowledge the shift from political discretion to legal obligation in WTO proceedings at any stage and its avoidance of Nakajima when it is "hard to envisage" a more relevant case, has been criticized by scholars. ${ }^{195}$

What is notable for our purposes concerning this WTO case law is the Court's disinclination to pick a clear course and stick to it. Instead, discretion is retained-at the expense of legal

\footnotetext{
${ }^{183}$ ECJ, Case C-69/89, Nakajima v. Council, ECLI:EU:C:1991:186 (July 5, 1991) https://curia.europa.eu/juris/documents.jsf? num $=$ C-69/89. See also supra notes 229-36 and accompanying text.

${ }^{184}$ See Biret International, Case C-93/02P at para. 74.

${ }^{185} \mathrm{Id}$. at para. 67.

${ }^{186}$ In addition to the already noted passages, the Court added, "[ $\mathrm{t}$ ] he purpose of the WTO agreements is to govern relations between States or regional organisations for economic integration and not to protect individuals." See id. at para. 72 .

${ }^{187}$ ECJ, Case C-377/02, Léon van Parys NV v. Belgisch Interventieen Restitutiebureau, ECLI:EU:C:2005:121 (Mar. 1, 2005), https://curia.europa.eu/juris/liste.jsf?language=en\&num $=\mathrm{C}-377 / 02$.

${ }^{188}$ Council Regulation 1637/98 of July 20, 1998, amending Regulation (EEC) No. 404/93 On the Common Organisation of the Market in Bananas, 1998 O.J. (L 210) 28 (EC).

${ }^{189}$ EeCKHOUT, supra note 53, at 364.

${ }^{190}$ Leon van Parys, Case C-377/02 at para. 50.

${ }^{191}$ Nakajima, Case C-69/89. Considered below, at Part 4.2.6.

${ }^{192} I d$. at para. 43 .

${ }^{193}$ Peter-Tobias Stoll \& Arthur Steinmann, WTO Dispute Settlement: The Implementation Stage, 3 Max PLANCK Y.B. United Nations L. 407, 411 (1999).

${ }^{194}$ DSU art. 21(3).

${ }^{195}$ See EECKHOUT, supra note 53, at 364. See also Piet Eeckhout, The Appellate Bodies and the Courts, in WTO LAW AND Process: The Proceedings of the 2005 And 2006 Annual WTO Conferences (Federico Ortino \& Sergey Ripinsky eds., 2007); Pieter Jan Kuijper, It Shall contribute to ... the Strict Observance and Development of International Law . . The Role of the Court of Justice, in The Court of Justice and the Construction of Europe: Analyses and Perspectives on Sixty YEARS OF CASE-LAW (Springer ed., 2013).
} 
certainty and applicants - even in circumstances where the Court appears to have backed itself into a corner. ${ }^{196}$

\section{Discretion Through Redeployment of the Conferral of Rights Test}

Building from experience, rather than principle, one may then simply need to think that WTO agreements are of a different ilk concerning their non-conferral of rights, among other things, precluding reliance. Indeed, commenting on Simutenkov, ${ }^{197}$ Jacobs notes that "it seems as if the nature of the Agreement is no longer an obstacle to direct effect, so long as the Agreement contains provisions which ... directly govern the position of individuals." 198 This case concerned a Partnership and Cooperation agreement, which creates a more limited relationship between parties than Association Agreements. ${ }^{199}$ In case law concerning the latter, it has been noted that the Court will often simply proceed to consider whether the specific provision a hand is sufficiently "clear, precise and unconditional" before then reflecting on the nature of the agreement. As Jacobs puts it, it would make little sense to consider a specific provision's direct effect only to refuse direct effect on the basis of the broad scope and logic of the agreement; accordingly, the Court has not done so. ${ }^{200}$ Therefore, there is a presumption towards direct effect; "[s]uch a reference [to the nature of the agreement] is perhaps a relic of an earlier period." 201

However, in Intertanko, ${ }^{202}$ which concerned the United Nations Convention on the Law of the Sea (UNCLOS), ${ }^{203}$ the Court reasoned that "individuals are in principle not granted independent rights and freedoms by virtue of UNCLOS" 204 and that "UNCLOS does not establish rules intended to apply directly and immediately to individuals and to confer upon them rights or freedoms capable of being relied upon against States, irrespective of the attitude of the ship's flag State." 205 The Court has been criticized heavily for its "curt" assertions and defensive stance concerning direct effect. ${ }^{206}$ It is also notable that in refusing direct effect, the Court also expressly closes the door on any possible argument concerning reciprocity in application of the agreement, unlike in WTO case law.

In Intertanko, Advocate General Kokott is suggested to have been "wrongfooted" 207 by the conclusion which the Court reached concerning the lack of direct effect. The confusion was still greater because, in Poulsen, a case concerning an EU Regulation seeking to control fishing on

\footnotetext{
${ }^{196}$ The uncertainty has prompted others to try-unsuccessfully_again. See ECJ, Case C-120/06, FIAMM and Others v. Council, ECLI:EU:C:2008:476 (Sept. 9, 2008), https://curia.europa.eu/juris/liste.jsf?num=C-120/06\&language=en; ECJ, Case C-306/13 LVP NV v. Belgische Staat, ECLI:EU:C:2014:2465 (Dec. 18, 2014), https://curia.europa.eu/juris/liste.jsf? num $=\mathrm{C}-306 / 13 \&$ language $=\mathrm{EN}$.

${ }^{197}$ ECJ, Case C-265/03, Simutenkov v. Ministerio de Educacion y Cultura and Others, ECLI:EU:C:2005:213, (Apr. 12, 2005), https://curia.europa.eu/juris/showPdf.jsf;jsessionid=9ea7d2dc30db1450f0974b954b61bb23bc1b656c831a.e34KaxiLc3qMb40Rch0 SaxuKaNr0? docid=66313\&pageIndex=0\&doclang $=$ EN\&mode $=1$ st\&dir $=\& o c c=$ first \&part $=1 \& \mathrm{cid}=4341448$.

${ }^{198}$ Francis G. Jacobs, The Internal Effects of the EU's International Agreements and the Protection of Individual Rights, in, A Constitutional Order of States?: Essays in Eu Law in Honour of Alan Dashwood 536 (Anthony Arnull et. al. eds., 2011).

${ }^{199}$ Maresceau, supra note 168 , at 426.

${ }^{200}$ See Jacobs, supra note 198 , at 532 .

${ }^{201} I d$. at 536.

${ }^{202}$ ECJ, Case C-308/06, Intertanko and Others, ECLI:EU:C:2008:312 (June 3, 2008), https://curia.europa.eu/juris/liste.jsf? language $=$ en $\&$ num $=\mathrm{C}-308 / 06$.

${ }^{203}$ Convention on the Law of the Sea, Dec. 19, 1982, 1833 U.N.T.S. 3, [hereinafter, UNCLOS].

${ }^{204} I d$. para. 59.

${ }^{205} \mathrm{Id}$. para. 64. The Court defensively added that doubt was not cast on this by Part XI of UNCLOS—addressing natural and legal persons exploration, use and exploitation of the ocean floor. See, id.

${ }^{206}$ See MendeZ, supra note 4, at 319. See also Jan Wouters \& Philip de Man, International Association of Independent Tanker Owners (Intertanko), International Association of Dry Cargo Shipowners (Intercargo), Greek Shipping Cooperation Committee, Lloyd's Register and International Salvage Union V. Secretary of State for Transport, 103 AM. J. INT'L. L. 555 (2009).

${ }^{207}$ MeNDEZ, supra note 4, at 275.
} 
the high seas, some rules within UNCLOS—which the EU was not yet party to-were applied analogously as CIL rules. Of course, not all UNCLOS rules will be CIL, but attention has been drawn to the fact that the Court did not even engage with this potential, ${ }^{208}$ let alone the ironic sequitur: Making UNCLOS formally binding on the EU simultaneously made it less enforceable.

In contrast to Intertanko, in $E D F,{ }^{209}$ the Court found direct effect of the Barcelona Convention for the Protection of the Mediterranean Sea against Pollution. Article 6(3) of the Convention provided that "discharges shall be strictly subject to the issue, by the competent national authorities, of an authorisation." ${ }^{210}$ However, a Commission action against France three months later confirmed that France had provided only "operating instructions" to EDF but that it was in breach of the Convention in doing so. ${ }^{211}$ This did not preclude a private individual from being able to rely on the Convention as against EDF in the interim, a conclusion which Pavoni notes the Court reached "without enquiring into whether the pertinent treaty norms on the regulation of pollution from land-based sources attributed rights to individuals." ${ }^{212}$ Mendez suggests that the explanation for the previous approach in EDF when compared to Intertanko was "the important distinctiona challenge to domestic rather than EU action." 213 This is a hidden factor, as it is one with which the Court has never been willing to engage in its case law, and suggests rules which vary according to latent discretion.

One may also speculate that in both cases the environment was protected, meaning that normative concerns may have led to two very different interpretations of what amounts to conferring rights. Ultimately, externally the conferral of rights test's resurgence has meant an additional means of utilizing discretion for the Court, particularly as it remains ill-defined.

\section{Discretion in Determining Whether a Specific Provision Within a Directly Effective Agreement May be Relied Upon}

The "clear, precise and unconditional" requirement of the test has been less problematic than that concerning "broad scope and logic." It has thus received less coverage in prominent accounts of the case law. ${ }^{214}$ A recent exception, though, notes flexibility and subjectivity in application of this element. ${ }^{215}$

Razanatsimba ${ }^{216}$ marked divergence from the internal rule concerning the specific wording of a provision, thereby providing a further locus for the Court to utilize its discretion. The case concerned the Lomé Convention, a former international trade and aid agreement between the EU and African Caribbean and Pacific countries. Article 62 of that agreement provided for non-discrimination concerning establishment unless "a Member is unable to provide such treatment." ${ }^{217}$ Mr. Razanatsimba was noted by the Court as seeking "to rely upon the principles

\footnotetext{
${ }^{208}$ Wouters \& de Man, supra note 206, at 557 adding that the "lapse is striking in view of the Court's express acknowledgment in Poulsen that many provisions of the LOS Convention were 'considered to express the current state of customary international maritime law'”. See id. at para. 10.

${ }^{209}$ ECJ, Case C-213/03, Syndicat Professionnel Coordination des Pêcheurs de l'Etang de Berre et de la Region v. EDF, ECLI: EU:C:2004:464 (July 15, 2004), https://curia.europa.eu/juris/liste.jsf?language=en\&num=C-213/03.

${ }^{210}$ Convention for the Protection of the Mediterranean Sea Against Pollution (Barcelona Convention), art. 6(3), Aug. 14, 1978, 27 U.N.T.S. 1102.

${ }^{211}$ ECJ, Case C-239/03, Commission v. France (Étang de Berre), ECLI:EU:2004:598, (Oct. 7,2004), para. 85, https://curia. europa.eu/juris/liste.jsf?language $=$ en $\&$ num $=\mathrm{C}-239 / 03$.

${ }^{212}$ See Pavoni, supra note 149, at 353. See similarly, Pal Wannerås, The ENFOrCEMENT of EC ENVIRONMENTAL LAW 25 (2007).

${ }^{213}$ Mendez, supra note 4, at 276.

${ }^{214}$ Holdgaard opts not to analyze it in his monograph on the basis that it "is largely identical to the internal direct effect test." See Holdgaard, supra note 15, at 273. See similarly Maresceau, supra note 168, at 295.

${ }^{215}$ Ghazaryan, supra note 24 , at 54 .

${ }^{216}$ ECJ, Case C-65/77, Razanatsimba, ECLI:EU:C:1977:193, (Nov. 24, 1977), https://curia.europa.eu/juris/liste.jsf? language $=$ en $\&$ num $=\mathrm{C}-65 / 77$.

${ }^{217}$ Convention of Lomé, art. 62, Feb. 28, 1975, O.J. (L 25/2).
} 
which form the basis of the judgment of the Court ... [in] Reyners." 218 The outcome of that case essentially found "that direct effect could apply even where the Member States possessed discretion, because the exercise thereof could be judicially controlled." ${ }^{19}$ Here though, the Court adopted a more restrictive reading by which a Member State or ACP State not adhering to non-discrimination "is not guilty of any infringement" but "merely exposes itself to the risk of a retaliatory measure by the other party." 220

The Court's conclusion and referral to what it termed "negative reciprocity" is interesting. In case law concerning agreements outside of GATT/WTO law, it has not often made reference to reciprocity, except often to note- as with this agreement - that the EU has undertaken asymmetrical obligations, and that accordingly the Court should enforce them. ${ }^{221}$ Perhaps then, the conditionality of the requirement here was the key to the Court's conclusion? Eeckhout considered that the Court "did not expressly rule on direct effect" and that "as the provision at issue contained an open-ended reservation, granting participating States a wide discretionary power, it was impossible to consider its direct application." ${ }^{222}$ But this does mark a significant divergence from Reyners. ${ }^{223}$ The case certainly evidences that the "specific provision" test is not, as is often suggested, equivalent to the internal test and that there is complexity within it.

This case may remain an anomaly, ${ }^{224}$ but the sheer presence of this case creates concerns where the "broad scope and logic" of an agreement has been found not to be problematic yet the Court may wish to limit the effects of it in a future case. Equally, the Court may be less inclined to preclude direct effect based on "broad scope and logic"225 — as this limits its discretion in the futureand so may make increased use of the "specific provision" test.

The Slovak Brown Bear case is perhaps evidence of the dexterity and usefulness of the "specific provision" test compared to the "broad scope and logic" test moving forward. ${ }^{226}$ Here, the Court was not inclined to overcome conditionality inherent in Article 9(3) of the Aarhus Convention, concerning access to justice, in order to require a Slovakian court to apply it directly so as to enable an organization to have greater access to justice in judicial review proceedings concerning environmental matters. ${ }^{227}$ Judicial review at EU level is notoriously narrow in scope for private individuals' standing. On this basis, it was inevitable that a case would arrive concerning not Member State rules on access to justice but EU rules. ${ }^{228}$ This may explain the fact that the

\footnotetext{
${ }^{218}$ Razanatsimba, Case C-65/77, para. 10, citing ECJ, Case C-2/74 Reyners v. Belgian State, ECLI:EU:C:1974:68, (June 21, 1974), https://curia.europa.eu/juris/liste.jsf?language=en\&jur=C,T,F\&num=2-74\&td=ALL.

${ }^{219}$ Paul Craig and Gráinne de Búrca, EU Law: Text, CASES AND Materials 190 (6th ed. 2015).

${ }^{220}$ Razanatsimba, Case C-65/77.

${ }^{221}$ See e.g., ECJ, Case C-87/75, Conceria Daniele Bresciani v. Amministrazzione Italiana delle Finanze dello Stato, ECLI:EU: C:1976:18, (Feb. 5, 1976), para. 23, https://curia.europa.eu/juris/liste.jsf?language=en\&jur=C,T,F\&num=87/75\&td=ALL.

${ }^{222}$ EeCKHOUT, supra note 53, at 333.

${ }^{223}$ See e.g., Alexander Somek, Monism: A Tale of the Undead, in Constitutional Pluralism In the European Union AND BEYOND 358 (Matej Abevlj \& Jan Komárek eds., 2012) (applying this principle to EU law itself).

${ }^{224}$ See e.g., Mendez, supra note 4, at 128, there Mendez describes Case C-18/90 ONEM v Kziber [1991] ECR I-199 as "the fountain from which nearly all later jurisprudential developments pertaining to social security provisions in Community Agreements have stemmed."; Mario Mendez, The legal effect of Community agreements: maximalist treaty enforcement and judicial avoidance techniques, 21 EUR. J. INT'L. L. 83, 92 (2010) (highlighting that "[t]he direct effect finding [in Kziber] bore a stark resemblance, unmentioned by the ECJ, to the approach to internal Community law as evinced most famously in the Reyners ruling where the absence of explicitly textually envisaged implementation measures was not permitted to stand in the way of the direct effect holding.").

${ }^{225}$ Not least due to the criticisms that often follow such a blanket finding, for example, regarding WTO law.

${ }^{226}$ ECJ, Case C-240/09, Lesoochranárske zoskupenie VLK v. Ministerstvo životného prostredia Slovenskej republiky ('Slovak Brown Bear'), ECLI:EU:C:2011:125, (Mar. 8, 2011), https://curia.europa.eu/juris/liste.jsf?language=en\&num=c240/09.

${ }^{227}$ For the argument that it should have, see Pavoni, supra note 149 , at 357.

${ }^{228}$ See id. at 360. See also EJC, Joined Cases $404 \&$ 405/12, Council and Commission v. Stichting Natuur en Milieu and Pesticide Action Network Europe, ECLI:EU:C:2015:5, (Jan. 13, 2015), https://curia.europa.eu/juris/liste.jsf?language=en\& num $=$ C-404/12\%20P.
} 
Court declined to grant direct effect of this specific provision despite direct effect of other Aarhus provisions being possible. The "specific provision" test here then provided delicacy in discretion that "broad scope and logic" tests cannot.

\section{Limited Discretion Through Presumed "Direct Effect" of Customary International law}

It will be discussed below ${ }^{229}$ that relative strength with which CIL is applied in the Court may be weaker than that of treaties to which the EU is a party. This is so as the Court today appears to limit its review of the legislator's action to "manifest errors in assessment." 330 Conversely, and likely because of this state of affairs, the potential for an individual to rely upon CIL has been more liberal. The case law has tended towards a presumption of direct effect, with the Court frequently simply stating that the EU "must respect international law in the exercise of its powers." 231

Air Transport ${ }^{232}$ saw a somewhat different approach to previous case law. In order to establish that the claimant could rely upon the international rule the Court focused on EU law. The international rule only had to be "capable of calling into question the competence of the European Union to adopt that act," ${ }^{33}$ however, the Union act had to be "liable to affect rights which the individual derives from European Union law or to create obligations under European law." ${ }^{234}$ Though odd-given that this was a preliminary reference and direct effect or quasi-direct effect of the EU provision is not typically a requirement-the latter test would frequently be met with ease. This test was indeed met in Air Transport as the claimant would, as an association of commercial airline operators, have been required to comply with the provisions of the directive. ${ }^{235}$

The approach to reliance on CIL still remains starkly more generous when compared with the labyrinth developments in international treaties to which the EU is a party; ${ }^{236}$ although we will see below that application of CIL is often weaker.

\section{Discretion Through Selective Application of Reference and Implementation Principles}

A variation to direct effect has manifested itself in the "implementation" and "reference" principles founded in the Nakajima ${ }^{237}$ and Fediol ${ }^{238}$ cases respectively. Koutrakos notes of the Fediol and Nakajima cases that to create this exception the court there viewed "the duties undertaken by GATT as 'internalised' in the Community legal order." 239 This raises questions regarding the

\footnotetext{
${ }^{229}$ See supra notes $142-150$ and accompanying text.

${ }^{230}$ ECJ, Case C-366/10, Air Transport Association of America and Others, ECLI:EU:C:2011:864 (Dec. 21, 2011), para. 110, http://curia.europa.eu/juris/liste.jsf?language=en\&num=C-366/10.

${ }^{231} I d$. at para 123; ECJ, Case C-162/96, Racke v. Hauptzollamt Mainz, ECLI:EU:C:1998:293, (June 16, 1998), para. 45, https:// curia.europa.eu/juris/liste.jsf?language $=$ en\&jur $=\mathrm{C}, \mathrm{T}, \mathrm{F} \&$ num $=\mathrm{C}-162 / 96 \& \mathrm{td}=\mathrm{ALL} ; \mathrm{ECJ}$, Case C-286/90, Anklagemindigheden v. Poulsen and Diva Navigation, ECLI:EU:C:1992:453, (Nov. 24, 1992), para. 9, https://curia.europa.eu/juris/liste.jsf?num=C286/90.

${ }^{232}$ Air Transport Association of America and Others, Case C-366/10.

${ }^{233} \mathrm{Id}$. at para. 107.

${ }^{234} I d$.

${ }^{235}$ Directive 2008/101/EC, of the European Parliament and of the Council of 19 November 2008 amending Directive 2003/ $87 / \mathrm{EC}$ so as to include aviation activities in the scheme for greenhouse gas emission allowance trading within the Community, 2009 O.J. (L 8/3).

${ }^{236}$ For a criticism of the Court's divergent approaches to international treaties and customary international law, see Jan Wouters \& Dries Van Eeckhoutte, The Enforcement of Customary International Law through EC Law, in DIRECT EFFECT: Rethinking a Classic of EC Legal Doctrine (J. M. Prinssen \& A. Schrauwen eds., 2004).

${ }^{237}$ ECJ, Case C-69/89, Nakajima v. Council, ECLI:EU:C:1991:186 (July 5, 1991) https://curia.europa.eu/juris/documents.jsf? num $=\mathrm{C}-69 / 89$.

${ }^{238}$ ECJ, Case C-70/87, Fediol v. Commission, ECLI:EU:C:1989:254, (June 22, 1989), https://curia.europa.eu/juris/ documents.jsf?num $=70 / 87$.

${ }^{239}$ Koutrakos, supra note 21 , at 262.
} 
assertion in Haegeman II which appeared to internalize all international treaties as an "integral part of [EU] law."240

Nakajima and Fediol would seem to provide that, notwithstanding a lack of direct effect, such agreements can provide a benchmark against which to review the legislature's actions. This potentially undermines the Court's reasons that such agreements preclude review generally due to their nature or lack of precision. Moreover, the fact that "there is no evidence that other WTO members have a similar exception [to Nakajima and Fediol]"241 undermines equally the rationale of reciprocity in the Court's WTO law more generally.

Confusion in this area is exacerbated by the Intertanko judgment. As the Court acknowledged, the directive provided that it would apply "in accordance with international law," with specific reference made to UNCLOS. ${ }^{242}$ But in spite of clear reference in the legislation to UNCLOS, the Court simply went on to highlight a lack of direct effect. Thus, in Intertanko the Court did not engage with the reference principle all, with no explanation of why this should be so. Though König considers that the directive in Intertanko could have remained intact were UNCLOS to be fully applied, ${ }^{243}$ others disagree. ${ }^{244}$ One cynical suggestion might be that in Fediol and Nakajima the challenges were ultimately unsuccessful.

However, though such a simplistic "meta-narrative" may provide a degree of legal certainty, Mendez draws attention to the fact that the General Court has annulled regulations and decisions on the basis of international $\operatorname{law}^{245}$ and that the Court has also done so in Petrotub. ${ }^{246}$ These cases all concerned anti-dumping rules and today scholars suggest that the reference and implementation principles are limited to GATT/WTO law, and probably only to anti-dumping within that; ${ }^{247}$ however, until recently the case law gave a very different impression.

In Bettati $^{248}$ an EU regulation was adopted in order to fulfil the commitments entered into under the Vienna Convention of 22 March 1985 for the Protection of the Ozone Layer. The Court stated that " $\mathrm{i}] \mathrm{t}$ is settled law that Community legislation must, so far as possible, be interpreted in a manner that is consistent with international law, in particular where its provisions are intended specifically to give effect to an international agreement concluded by the Community." 249 Though conflation of indirect effect-a mere interpretative tool-and the implementation principle - a basis for review-rendered the Court's position less clear, there was an implication that the implementation principle could be relevant beyond anti-dumping and even WTO case law.

\footnotetext{
${ }^{240}$ ECJ, Case 181/73, Haegeman v. Belgium, ECLI:EU:C:1974:41, (Apr. 30, 1973), paras. 4-6, https://curia.europa.eu/juris/ liste.jsf?num $=\mathrm{C}-181 / 73$.

${ }^{241}$ MeNDEZ, supra note 4, at 238.

${ }^{242}$ See Intertanko and Others, Case C-308/06, at para. 24 (citing Council Directive 2005/35/EC of the European Parliament and of the Council of 7 September 2005 on ship-source pollution and on the introduction of penalties, particularly criminal penalties, for infringements, 2005 O.J. (L322/8), art. 3(1)).

${ }^{243}$ Doris König, The EU Directive on Ship-Source Pollution and on the Introduction of Penalties for Infringements: Development or Breach of International Law?, in LAW of THE SEA, Environmental LAW ANd SeTtlement of Disputes: Liber Amicorum Jude Thomas A. Mensah (Tafsir Malick Ndiaye \& Rüdiger Wolfrum eds., 2007). See also, ECJ, Case C-308/06, Interanko and Others, ECLI:EU:C:2007:689 (Nov. 20, 2007), http://curia.europa.eu/juris/liste.jsf?language=en\& num $=$ C-308/06

${ }^{244}$ MeNDEZ, supra note 4, at 100.

${ }^{245} \mathrm{Id}$. at 302 .

${ }^{246}$ ECJ, Case C-76/00P, Petrotub v. Council, ECLI:EU:C:2003:4, (Jan. 9, 2003), https://curia.europa.eu/juris/liste.jsf? language $=$ en $\&$ num $=\mathrm{C}-76 / 00 \% 20 \mathrm{P}$.

247"In any event the case law has gradually reduced the scope for invoking the principle ... [except] in the field of antidumping." See EeCKHOUT, supra note 53, at 361. See similarly, Szilard Gáspár-Szilágyi, The Relationship Between EU Law And International Agreements: Restricting The Application Of The Fediol And Nakajima Exceptions In Vereniging Milieudefensie, 52 COMmon MKt. L. Rev. 1059 (2015); Koutrakos, supra note 21, at 306.

${ }^{248}$ ECJ, Case C-341/95, Bettati v. Safety Hi-Tech Srl, ECLI:EU:C:1998:353, (July 14, 1998), https://curia.europa.eu/juris/liste. jsf?language $=$ en $\&$ num $=\mathrm{C}-341 / 95$.

${ }^{249} I d$. at para. 20.
} 
Racke ${ }^{250}$ confirmed this further by applying the principle to CIL. The Court identified that the challenged regulation, which suspended an international agreement with the Socialist Federal Republic of Yugoslavia, had been adopted so as to comply with CIL governing the suspension of such agreements. ${ }^{251}$ The Court drew direct analogies between invocation of CIL and the Nakajima principle in the judgment ${ }^{252}$ and conducted a review of EU secondary legislation in light of international rules, ostensibly on the basis of that principle. ${ }^{253}$

Commune de Mesquer ${ }^{254}$ saw the Court return to the principle in passing-although without a direct reference to Fediol or Nakajima-concerning various conventions providing for liability caps in the event of oil pollution. Ultimately the precise directive at hand did not, rather conveniently for the Court, refer to international conventions on liability, leaving it free to impose a higher level of liability in total. But the clear prospect of applying the implementation principle beyond WTO law once more rendered Intertanko all the more questionable, particularly as Commune de Mesquer was decided after Intertanko.

The above has so far shown little clarity as to who exactly is in the driving seat regarding the reference and implementation exceptions: Is it the legislature? The Court on an overtly ad hoc basis? Or is it dependent on the type of international agreement or customary rule?

Stichting saw the General Court and Court disagree profoundly. Though the General Court found that the regulation "was adopted to meet the European Union's international obligations under Article 9(3) of the Aarhus Convention," 255 the Court ruled that "it cannot be considered that, by adopting Regulation No 1367/2006 . . the European Union was intended to implement the obligations [of the Aarhus Convention]." 256 Gáspár-Szilágyi notes that this was held despite "the more than obvious title which specifically refers to the Aarhus Convention [and the fact that] almost every recital of the preamble of the Regulation makes references to the Convention." 257

Ultimately the Court "came clean" and stated of Nakajima and Fediol, "those two exceptions were justified solely by the particularities of the agreements that led to their application." 258 This overturned the more liberal approach of the General Court, which had relied on the Nakajima principle and ultimately annulled the regulation on the basis of the Convention. The fact that the Court neglected even to mention Racke, which formed a cornerstone in the General Court's reasoning in evidencing the principle's application beyond GATT/WTO law, ${ }^{259}$ is also a strong indication of the principle's limitations today. However, caution is warranted given the Court's tendency to repurpose seemingly dormant judicial devices. ${ }^{260}$

\footnotetext{
${ }^{250}$ ECJ, Case C-162/96, Racke v. Hauptzollamt Mainz, ECLI:EU:C:1998:293, (June 16, 1998), https://curia.europa.eu/juris/ liste.jsf?language $=$ en $\&$ jur $=\mathrm{C}, \mathrm{T}, \mathrm{F} \&$ num $=\mathrm{C}-162 / 96 \& \mathrm{td}=\mathrm{ALL}$.

${ }^{251} I d$. at para. 19.

${ }^{252}$ Racke is invoking fundamental rules of customary international law against the disputed regulation, which was taken pursuant to those rules, and deprives Racke of the rights to preferential treatment granted to it by the Cooperation Agreement. For a comparable situation in relation to basic rules of a contractual nature, see ECJ, Case C-69/89, Nakajima v. Council, ECLI: EU:C:1991:186 (July 5, 1991), paras. 31 \& 48, https://curia.europa.eu/juris/documents.jsf?num=C-69/89.

${ }^{253}$ Concerning the controversy over the Court's interpretation of CIL, see below at 4.3.1.

${ }^{254}$ ECJ, Case C-188/07, Commune de Mesquer v. Total France SA and Total International Ltd, ECLI:EU:C:2008:359, (June 24, 2008), https://curia.europa.eu/juris/liste.jsf?language=en\&num=C-188/07.

${ }^{255}$ ECJ, Case T-338/08, Stichting Natuur en Milieu and Pesticide Action Network Europe v. European Commission, ECLI: EU:T:2012:300, (June 14, 2012), para. 58, https://curia.europa.eu/juris/liste.jsf?num=T-338/08.

${ }^{256}$ EJC, Joined Cases 404 \& 405/12, Council and Commission v. Stichting Natuur en Milieu and Pesticide Action Network Europe, ECLI:EU:C:2015:5, (Jan. 13, 2015), https://curia.europa.eu/juris/liste.jsf?language=en\&num=C-404/12\%20P.

${ }^{257}$ Gáspár-Szilágyi, supra note 246 , at 1063.

${ }^{258}$ EJC, Joined Cases 404 \& 405/12, Council and Commission v. Stichting Natuur en Milieu and Pesticide Action Network Europe, ECLI:EU:C:2015:5, (Jan. 13, 2015), para. 49, https://curia.europa.eu/juris/liste.jsf?language=en\&num=C-404/12\% $20 \mathrm{P}$.

${ }^{259}$ See ECJ, Stichting Natuur en Milieu, Case T-338/08 at para. 56.

${ }^{260}$ For example, the conferral of rights test.
} 


\section{Manifestations of Discretion in External Relations Case Law II: Application of International Law}

Holdgaard observes "[ $t$ ]he hierarchical status of international agreements concluded by the Community has never been much disputed," 261 sitting above secondary legislation but below the Treaty. CIL is ranked similarly. Of course, "the practical effect of a hierarchically superior rule of international law depends on whether or not it can be directly invoked." 262 If granted, hierarchy would simply dictate mechanical application of a superior rule to invalidate a lower ranked one. However, the multifaceted discretion accruing to the Court through modifications to direct effect above has not proven sufficient to redress the absence of proportionality. Accordingly, we can now chart some further modifications which have also enhanced the Court's discretion at the application stage.

\section{Discretion Through Opportunistic Interpretations of Provisions of International Agreements and $\mathrm{CIL}$}

This Article has identified above that the Court has taken a more liberal view towards the invocation of CIL than it has to international agreements. However, it appears the Court has limited its view of what CIL demands.

In Woodpulp, ${ }^{263}$ the Court dealt with a challenge that Article 101 TFEU was being applied extraterritorially, as an agreement to restrict competition had been concluded outside of the EU. However, its effect was to restrict competition within the EU. Therefore the Court asserted that "the Community's jurisdiction to apply its competition rules to such conduct is covered by the territoriality principle as universally recognised in public international law." 264 The implication though was that EU action, and even the EU Treaty, would be appropriately constrained by CIL.

However, Intertanko demonstrates that the Court will not necessarily be quick to accept that international rules reflect custom. In Poulsen the Court said of UNCLOS that "many of its provisions are considered to express the current state of customary international maritime law." ${ }^{265}$ In Intertanko the Court stated:

Admittedly, as is clear from settled case-law, the powers of the Community must be exercised in observance of international law, including provisions of international agreements in so far as they codify customary rules of general international law . . . ${ }^{266}$

The Court cited Poulsen, but it did not clearly address UNCLOS in this regard. Even the later statement that "UNCLOS's main objective is to codify, clarify and develop the rules of general international law" ${ }^{267}$ did not prompt the Court to do so. The lack of analysis in Intertanko in this regard has been said to be striking. ${ }^{268}$

Where accepted as relevant, case law has also shown the complexities which can arise concerning interpretations of CIL. The decisions have been met with some criticism. Opel Austria, ${ }^{269}$

\footnotetext{
${ }^{261}$ Holdgaard, supra note 15 , at 245.

${ }^{262} I d$.

${ }^{263}$ ECJ, Joined Cases 89 \& 104/85, Ahlström Osakeyhtiö and Others v. Commission of the European Communities, ECLI: EU:C:1994:12, (Jan. 20, 1994), https://curia.europa.eu/juris/showPdf.jsf?text=\&docid=93657\&pageIndex=0\&doclang=en \& mode $=1$ st $\&$ dir $=\& o c c=$ first $\&$ part $=1 \&$ cid $=1607495$.

${ }^{264} I d$. at para 18.

${ }^{265}$ ECJ, Case C-286/90, Anklagemindigheden v. Poulsen and Diva Navigation, ECLI:EU:C:1992:453, (Nov. 24, 1992), para. 10, https://curia.europa.eu/juris/liste.jsf?num=C-286/90.

${ }^{266}$ See ECJ, Case C-308/06, Intertanko and Others, ECLI:EU:C:2008:312 (June 3, 2008), para. 51, https://curia.europa.eu/ juris/liste.jsf?language $=$ en\&num $=\mathrm{C}-308 / 06$.

${ }^{267} I d$. at para. 55 .

${ }^{268}$ Wouters \& de Man, supra note 206, at 557.

${ }^{269}$ ECJ, Case T-115/94, Opel Austria v. Council, ECLI:EU:T:1997:3, (July, 15, 1998), ECR II-39, https://eur-lex.europa.eu/ LexUriServ/LexUriServ.do?uri=CELEX:61994TJ0115:EN:PDF
} 
a case at the General Court (then CFI), is notable in that it saw the rare occurrence of EU secondary law being invalidated where international law was invoked. However, on closer inspection, the extent to which international law formed the basis for invalidation, rather than the EU principle of legitimate expectations, emerges as questionable. The case concerned the adoption of a regulation which was argued to be in breach of a signed, but not yet in force, EEA treaty. ${ }^{270}$ The General Court held that "the principle of good faith is a rule of customary international law."271 However, it found it to be a "corollary ... of the [EU general] principle of protection of legitimate expectations." ${ }^{272}$ Ultimately the General Court referred to the regulation as having "infringed the applicant's legitimate expectations" 273 rather than the principle of good faith. Eeckhout notes that the principle was "channeled" 274 throughout EU law. Konstadinides takes a sterner approach in stating that "despite the custom-friendly outcome," ${ }^{275}$ in reality "[i]t makes more sense to argue that the customary principle of good faith was not the real ground for annulment." 276 This suggestion is further supported by the Air Transport ${ }^{277}$ case, concerning airline emissions, which further limited the extent to which CIL - in and of itself-is a genuine restraint on EU action. The Court found that ${ }^{278}$ :

[S] ince a principle of customary international law does not have the same degree of precision as a provision of an international agreement, judicial review must necessarily be limited to the question whether, in adopting the act in question, the institutions of the European Union made manifest errors of assessment concerning the conditions for applying those principles. ${ }^{279}$

Accordingly, a "manifest errors" approach, which was not present in the review on the basis of EU law in Opel Austria, is present here where CIL alone is applied, with Racke being cited as justification. However, it is submitted that the reference to Racke is misleading. In Racke the Court did conclude that "the complexity of the rules in question and the imprecision of some of the concepts to which they refer" 280 meant that only a marginal review of the legislator's actions could be conducted. However, the reference was not to all rules of customary law but to "the rules of customary international law concerning the termination and the suspension of treaty relations by reason of a fundamental change of circumstances." ${ }^{281}$ It is notable that even concerning Racke this approach was criticized. ${ }^{282}$

Notwithstanding Racke, the Court's approach to interpreting CIL in Air Transport itself can be questioned. Territorial sovereignty is arguably the precursor to the proper functioning of international law. ${ }^{283}$ The extension of the concept to airspace is both essential for the proper

\footnotetext{
${ }^{270}$ The Court noted that "the Communities were aware of the date on which the EEA Agreement would enter into force" seven days before conclusion of the contested regulation as they had been the final signatory to approve it. $I d$. at para. 92 .

${ }^{271} I d$. at para. 90.

${ }^{272} I d$. at para. 93 .

${ }^{273} I d$. at para. 123.

${ }^{274}$ EECKHOUT, supra note 53, at 387.

${ }^{275}$ Theodore Konstadinides, When in Europe: Customary International Law and EU Competence in the Sphere of External Action, 13 German. L. J. 1177, 1187 (2012).

${ }^{276} \mathrm{Id}$. at 1188 .

${ }^{277}$ ECJ, Case C-366/10, Air Transport Association of America and Others, ECLI:EU:C:2011:864 (Dec. 21, 2011), para. 110, http://curia.europa.eu/juris/liste.jsf?language=en\&num $=$ C-366/10.

${ }^{278} I d$. at para. 110.

${ }^{279}$ See ECJ, Case C-162/96, Racke v. Hauptzollamt Mainz, ECLI:EU:C:1998:293, (June 16, 1998), para. 52, https://curia. europa.eu/juris/liste.jsf?language $=$ en $\&$ jur $=\mathrm{C}, \mathrm{T}, \mathrm{F} \&$ num $=\mathrm{C}-162 / 96 \& \mathrm{td}=\mathrm{ALL}$.

${ }^{280} I d$.

${ }^{281} I d$. at para. 46.

${ }^{282}$ Wouters \& Van Eeckhoutte, supra note 235, at 206-07.

${ }^{283}$ S.S. Lotus (Fr. V. Turk.), Judgement, 1927 P.C.I.J. (ser. A) No. 10, at para. 45 (Sept. 7).
} 
functioning of aviation and uncontroversial. The ICJ describes the rule concerning sovereignty over airspace as a "basic legal concept," ${ }^{284}$ confirming "no doubt that . . . prescriptions of treaty-law ${ }^{285}$ merely respond to firmly established and longstanding tenets of customary international law." 286 This does not sit well with the Court's assertion that the rule lacked precision. ${ }^{287}$

Arguably, the outcome simply evidences the problem by which environmental protection has developed in importance in more recent years, a development with which external relations case law, based in hierarchy and formalism, has struggled to keep up. Advocate General Kokott appeared to acknowledge this problem and encourage change in stating:

[The Court's] judgment will be of fundamental importance not only to the future shaping of European climate change policy but also generally to the relationship between European Union (EU) law and international law. In particular it will be necessary to consider whether and to what extent individuals are entitled to rely in court on certain international agreements and principles of customary international law in order to defeat an act of the European Union. ${ }^{288}$

Though the Court was not so colorful, it did refer to the importance of "environmental protection objectives which it has set for itself." ${ }^{289}$ But, as Koutrakos points out, this point was irrelevant in the current constellation of the case law. ${ }^{290}$ Although few would question that it did, in fact, influence the Court.

Moreover, if we reconsider Air Transport, which concerned the expansion of the EU emissions trading scheme to airlines, in light of Arcelor, which also featured the expansion of the emissions trading scheme to steel producers, then a further impact of the absence of proportionality is apparent. In Arcelor the Court provided a margin to the legislature as it should have a "broad discretion where its action involves political, economic and social choices." ${ }^{291}$ From the legislature's perspective though, it is clear which expansion was more complex, ${ }^{292}$ but the Court's rules governing reception and application of international law could not accommodate this, hence the interpretative strain to find CIL uncertain.

It is not just CIL which has seen strained interpretation. A prominent example of opportunistic interpretation of an international treaty is ELFAA. ${ }^{293}$ The case saw a challenge to an EU regulation on the basis that it breached the Montreal Convention. The Montreal Convention provides for the

\footnotetext{
${ }^{284}$ Military And Paramilitary Activities In And Against Nicaragua (Nicar. v. U.S.) Judgment, 1986 I.C.J. 14, para. 212 (June 27).

${ }^{285}$ The ICJ made reference inter alia to the Chicago Convention on International Civil Aviation, Dec. 7, 1944, 15 U.N.T.S. 295.

${ }^{286}$ Military and Paramilitary Activities in and against Nicaragua (Nicar. v U.S.) Judgment, 1986 I.C.J. 14, para. 212. Shaw notes that the principle of territorial sovereignty over airspace developed "very quickly in the years immediately before and during the First World War.” See, Malcolm N. ShaW, InTernational LaW 55 (7th ed. 2014).

${ }^{287}$ ECJ, Case C-366/10, Air Transport Association of America and Others, ECLI:EU:C:2011:864 (Dec. 21, 2011), para. 110, http://curia.europa.eu/juris/liste.jsf?language=en\&num $=$ C-366/10.

${ }^{288}$ See Opinion of Advocate General Kokott at para. 4, Case C-366/10, Air Transport Association of America and Others (Oct. 6, 2011), http://curia.europa.eu/juris/liste.jsf?language=en\&num=C-366/10.

${ }^{289}$ See Air Transport, Case C-366/10 at para. 128.

${ }^{290}$ Koutrakos, supra note 21 , at 318.

${ }^{291}$ ECJ, Case C-127/07, Société Arcelor Atlantique et Lorraine and Others v. Premier Minister, ECLI:EU:C:2008:728 (Dec. 16, 2008), para. 57, http://curia.europa.eu/juris/liste.jsf?language=en\&num=C-127/07.

${ }^{292}$ On complexity of international affairs requiring a "wide discretion" for the legislature generally, see KouTRAKOS, supra note 21 , at 183 . On the "climate change regime complex" specifically, see Joanne Scott \& Lavanya Rajamani, EU Climate Change Unilateralism, 23 EUR. J. INT'L. L. 469, 470 (2012).

${ }^{293}$ ECJ, Case C-344/04, IATA and ELFAA, ECLI:EU:C:2006:10 (Jan. 10, 2006), http://curia.europa.eu/juris/liste.jsf? language $=$ en $\&$ num $=$ C-344/04.
} 
circumstances and amount of compensation to which passengers are entitled. The EU is a party to the Montreal Convention and the Court found the relevant articles of the Convention to have direct effect. ${ }^{294}$ It then referred to Article 31 of the Vienna Convention on the Law of Treaties (VCLoT) and directed itself that an international treaty "must be interpreted . . . in good faith in accordance with the ordinary meaning to be given to its terms in their context and in the light of its object and purpose."295

However, in spite of the Court acknowledging the Montreal Convention limiting liability of carriers to set amounts, ${ }^{296}$ the Court reasoned that "[t]he system prescribed in Article 6 [of the regulation] simply operates at an earlier stage than the system which results from the Montreal Convention." 297 Thus the challenge was unfounded; the EU legislature was free to impose liability, even in extraordinary circumstances, as the Court felt that it was regulating a distinct aspect of compensation not covered by the Convention.

The Court reasoned that the Convention covered individual damage sustained by passengerswho could then bring a claim-but that the regulation covered "standardised and immediate assistance." ${ }^{298}$ The Court implicitly acknowledges the potential for some overlap with the Convention, stating " $\mathrm{t}]$ he standardised and immediate assistance and care measures do not themselves prevent the passengers concerned, should the same delay also cause them damage conferring entitlement to compensation, from being able to bring in addition actions to redress that damage under the conditions laid down by the Montreal Convention." 299

In spite of passengers not being able to claim twice for the same damage, there is the problem that the 4150 SDRs cap is now artificially raised. Mendez also draws attention to the fact that the Convention contains an exclusivity provision, allowing for passengers to seek damages only through it. ${ }^{300}$ Overall there is heavy criticism of the reasoning adopted by the Court. ${ }^{301}$

It is submitted that Air Transport and ELFAA ultimately appear as contorted interpretative efforts deployed to pursue environmental protection and consumer protection, respectively. The norms of consumer and environmental protection are indeed important, but their accommodation through the finding of interpretative room within international provisions that appear to allow none is problematic for legal certainty. Proportionality analysis would have provided for richer argumentation and engagement with the facts and, given the heavy criticism of both cases, could not have damaged perceptions of the EU's respectfulness towards EU law any further.

\section{Discretion Through Recourse to the Concept of an Autonomous Legal System}

The EU legal system "cannot be prejudiced by an international agreement." 302 This infamous phrase in fact belies the outcome of the Kadi case law. As is well known, in Kadi the Court was confronted with an EU regulation which transposed a UN Security Council Resolution aimed at combatting terrorism by listing terrorist suspects and suspected financiers. The potential infringement on fundamental rights was subjected to a limited review on the basis of jus cogens by the General Court, in deference to the international origin of the EU regulation. The Court instead reviewed the EU Regulation on the basis of EU law and made that clear through the language of autonomy. But on closer inspection, the autonomous legal system is quite permeable.

\footnotetext{
${ }^{294} I d$. at para. 39.

${ }^{295} \mathrm{Id}$. at para. 40.

${ }^{296} I d$. at para. 42.

${ }^{297} I d$. at para. 46.

${ }^{298} I d$. at para. 43.

${ }^{299} I d$. at para. 47.

${ }^{300} \mathrm{MeNDEZ}$, supra note 4 , at 270.

${ }^{301}$ See e.g., id. at 269-270; Aust, Rodiles \& Staubach, supra note 38, at 75; B. Harris, The 'Force Of Law' Of International Carriage Conventions In The EU Internal Market, 25 InT'L COMPANY \& COM. L. Rev. 98, 105-6 (2014).

${ }^{302}$ ECJ, Joined Cases 402 \& 415/05P, Kadi and Al Barakaat International Foundation v. Council and Commission (Kadi I), ECLI:EU:C:2008:461, Judgement of Sept. 3, 2008, at 316, https://curia.europa.eu/juris/liste.jsf?num=C-402/05.
} 
"The Court must determine whether a fair balance has been struck between the demands of the public interest and the interest of the individuals concerned" and that public interest must be judged " $[w] i t h$ reference to an objective of general interest as fundamental to the international community as the fight by all means ... against the threats to international peace and security posed by acts of terrorism." ${ }^{\text {303 }}$ Accordingly the international political and legal context permeated the "autonomous" EU legal system and was balanced against the "very foundations" of that legal system. ${ }^{304}$ However, due to the significant shortcomings in the listing process the Court's application of this balance is less discernible.

It is notable though that while the Court noted the multiple flaws in the regulation ${ }^{305}$ it concluded "annulment to that extent of the contested regulation with immediate effect would be capable of seriously and irreversibly prejudicing the effectiveness of the restrictive measures imposed by the regulation and which the Community is required to implement . . ." 306

The Court accordingly allowed the regulation to maintain its effects for three months, within which time a new regulation was concluded. Thus, in spite of the fact that multiple infringements of fundamental rights were found, the remedy was simply to provide the legislature with a further three months in which to remedy the shortcomings. This is markedly deferential to international law and, of course, recognizes the importance of combatting terrorism, which it would be artificial to suggest is purely an EU, and not international, concern. The consequence was that a new Security Council Resolution was passed, transposed into EU law, and then challenged once more in Kadi II. Five years had passed since the Court's Kadi I judgment in which the EU legal system had been declared to be unable to be prejudiced by international law.

Far from "autonomy," Sena and Vitucci's argument that "the findings reached in its judgment can, ultimately, be regarded as the outcome of a direct balancing of the EC principles on fundamental rights with the value of cooperation of the EU states with the UN in the fight against terrorism" 307 seems correct. Autonomy here was simply proportionality by another name.

However, autonomy has meant autonomy in cases such as MoxPlant, precluding Member State submission of a dispute to an international court where EU law is concerned, ${ }^{308}$ and Opinion 2/13, refusing accession to the ECHR. ${ }^{309}$ Equally though it has not been mentioned in cases where it appeared relevant. ${ }^{310}$

Though Kadi I shows that autonomy can have a softer and more proportionate side, the deployment of autonomy is guaranteed to garner much attention and for this reason the term may have been eschewed in Kadi II. Interestingly, though, the Court returned to autonomy in Opinion 2/13. Ultimately then the concept itself is elusive and allows for discretion in both deployment and application, yet falling short of that which proportionality would offer. The label of autonomy is unhelpful, but the concept of autonomy is confirmatory of the discretion which a domestic court holds when applying international law. The manifestation of that discretion, though, would be better served through proportionality.

\footnotetext{
${ }^{303} I d$. at para. 360.

${ }^{304} I d$. at para. 344 .

${ }^{305} I d$. at para 348 ; Id. at paras. $369-370$.

${ }^{306} I d$. at para 373 .

${ }^{307}$ Pasquale De Sena \& Maria Chiara Vitucci, The European courts and the Security Council: Between Dedoublement Functionnel and Balancing of Values, 20 EUR. J. INT'L. L. 193, 224 (2009).

${ }^{308}$ ECJ, Case C-459/03, Commission v. Ireland, ECLI:EU:C:2006:345, (May 30, 2006), https://curia.europa.eu/juris/liste.jsf? num $=\mathrm{C}-459 / 03$.

${ }^{309}$ ECJ, Case C-2/13, Opinion re Accession of the European Union to the European Convention for the Protection of Human Rights and Fundamental Freedoms, ECLI:EU:C:2014:2454, (Dec. 14, 2014), https://curia.europa.eu/juris/document/document. jsf? docid $=160882 \&$ doclang $=\mathrm{EN}$.

${ }^{310}$ See e.g., ECJ, Case C-584/10, Commission and others v. Kadi ('Kadi II'), ECLI:EU:C:2013:518, (July 18, 2013), https:// curia.europa.eu/juris/liste.jsf?num=C-584/10; ECJ, Case C-364/10, Hungary v. Slovakia, ECLI:EU:C:2012:630, (Oct. 16, 2012), https://curia.europa.eu/juris/liste.jsf?num $=\mathrm{C}-364 / 10 \&$ language $=\mathrm{EN}$ stating that fundamental freedom of movement of the Hungarian President was curtailed based on the international treaty and CIL.
} 


\section{External Relations Cases Which Have Seen the Deployment of Proportionality}

It is appropriate to end our analysis of the case law with an anomaly or two: The Court's deployment of proportionality analysis in the application of international law.

Omega Air ${ }^{311}$ concerned secondary legislation which sought to limit noise pollution of aircraft. The Court engaged with the principle of proportionality and stated that "with respect to judicial review ... the Community legislature has wide legislative powers in the field of the common transport policy as regards the adoption of appropriate common rules." 312 In favorably reviewing the legislature's actions, the Court even invoked ICAO assembly resolutions, which it claimed endorsed the approach adopted by the EU. ${ }^{313}$

Though the Court would later expressly recall the fact that WTO law does not have direct effect, the passages concerning proportionality appear implicitly to disentangle international provisions in both WTO law and the Chicago Convention - to which the EU is not even party-from the need for direct effect for the purposes of that analysis. ${ }^{314}$ Overall, the balance between respect for international law and protection of the environment appeared to be entertained.

Commission v. Italy also saw deployment of proportionality. ${ }^{315}$ The case concerned a Free Trade Agreement with Norway. In finding Italy in breach of the agreement, the Court reasoned that due to provisions analogous to Article 34 and 36 TFEU, Italy's requirement for health inspections of fish had "infringed the principle of proportionality." 316 This application of proportionality is interesting as it concerns a balance within the international agreement rather than between protection of EU law and respect for international law.

However, Eeckhout points out that in Commission v. Italy the deployment of proportionality "[found] little basis in the actual agreement." 317 The international treaty provision allowed for measures to protect, inter alia, health, provided they do "not constitute a means of arbitrary discrimination or a disguised restriction on trade between the Contracting Parties," whereas here the Court balanced the health imperative against the trade imperative, as it would do in internal case law.

The effort to conclude trade agreements which more appropriately reflect non-trade concerns within them means that this approach may be available to the Court more often, meaning at least a limited role for proportionality moving forward. ${ }^{318}$

\section{Reflections on Diffuse Discretion in External Relations Case Law}

In internal case law the Court's discretion does not reside exclusively within the proportionality test, but it is its primary residence. This is the consequence of accepting reliance on rules without requiring direct effect in many instances. ${ }^{319}$ Equally, where direct effect is required ${ }^{320}$ we have seen a remarkably liberal approach in finding it to be present. With EU law readily engaged, the Court's

\footnotetext{
${ }^{311}$ ECJ, Joined Cases 27 \& 122/00, Omega Air and Others, ECLI:EU:C:2002:161, (Mar. 12, 2002), https://curia.europa.eu/ juris/liste.jsf?language $=$ en\&num $=\mathrm{C}-27 / 00$.

${ }^{312} \mathrm{I} d$. at para. 63 .

${ }^{313} \mathrm{Id}$. at para. 70 .

${ }^{314}$ The Advocate General also applied the proportionality test. Opinion of Advocate General Alber at paras. 61-87, Cases 27 \& 122/00, Omega Air and Others (Mar. 12, 2002).

${ }^{315}$ ECJ, Case C-228/91, Commission v. Italy, ECLI:EU:C:1993:206, (May 25, 1993), https://eur-lex.europa.eu/legal-content/ EN/TXT/?uri=CELEX\%3A61991CJ0228\#SM

${ }^{316} I d$. at para. 49.

${ }^{317}$ EeCKHOUT, supra note 53, at 318.

${ }^{318}$ See e.g., Lonel Zamfir, European Parliamentary Research Service, Human Rights in EU Trade Agreements: The Human Rights Clause And Its Application, (July 2019), https:/www.europarl.europa.eu/RegData/etudes/BRIE/2019/637975/EPRS_ BRI(2019)637975_EN.pdf.

${ }^{319}$ TFEU arts. 258, 259, 263; TFEU art. 267.

${ }^{320}$ TFEU art. 267.
} 
practice is to then postulate competing interests at the same level and to resolve them with consideration of the unique facts of the given case in a proportionality analysis.

Externally, direct effect has been more actively deployed as a gatekeeper of the EU legal order. Perhaps this is to be expected given that direct effect was justified by the EU being, in the Court's view, "a new legal order of international law." ${ }^{321}$ However, complexity in external relations cases arises due to the sheer breadth of the rules, not to mention their variation over time. A further confounding feature is that the rules of direct effect seem to be heavily influenced by unexpressed normative concerns to the point where one wonders "whether . . . the actual review which the judgment avoids, is influencing the answer ... as to the capacity of the Agreement itself to form a review criterion vis-à-vis Community law." 322

Moreover, overburdening direct effect as a locus for discretion clearly lacks the refinement of proportionality analyses. Pavoni notes this problem in Intertanko; by refusing direct effect of a significant number of UNCLOS provisions, the case led to higher environmental protection but would, in theory, be equally applicable to EU and Member State conduct in a subsequent case and accordingly may result in "lower EU standards of environmental protection" in the future. ${ }^{323}$

Similarly, interpreting away the demands of international law, through eminently subjective readings of international treaties or claimed uncertainties of CIL which few international scholars would recognize, ${ }^{324}$ may ultimately protect EU norms, but it does so by mutating the international norm itself rather than balancing interests in a given case. This too renders it hard to recant from in a subsequent case with fresh competing interests.

Ultimately, where proportionality has become dominant in resolving internal complexity, external recourse to it - in name at least-is a statistical outlier. This results in fragmented case law which can at times seem capricious, at least until one considers normative factors hidden behind judgments. Legal certainty is clearly affected by the continued purport of neutrality and a formal hierarchy, with normative concerns permeating without a clear rationale or measured resolution and in stark contrast to internal case law.

\section{How Could Proportionality in External Case Law be Expanded in the Future?}

From the above we can see a significant fragmentation in approaches and even divergences within individual approaches. It has been argued that these seemingly narrow and often technical distinctions are best understood through a normative lens. Proportionality is the purest expression of that normative lens available within EU law.

The sheer presence of proportionality will lessen the pressure on direct effect related rules and the uncertainty it creates. For example, a finding of direct effect would no longer be fatal to a piece of EU secondary legislation as it may be justified at the proportionality stage. ${ }^{325}$ For a similar reason, international law would also be less susceptible to being imputed with questionable meaning as an avoidance strategy. ${ }^{326}$ This is particularly important given that although application of international law — through direct effect tests - is readily accepted as being within the discretion of domestic courts, interpretation of international law is not. Accordingly, though d'Aspremont and Dopagne suggest there is an "elementary divide" 327 between the application of international law at

\footnotetext{
${ }^{321}$ van Gend en Loos, Case C-26/62 at 12.

${ }^{322}$ MendeZ, supra note 4 , at 100 .

${ }^{323}$ Pavoni, supra note 149 , at 356.

${ }^{324}$ Wouters \& Van Eeckhoutte, supra note 235, at 230-31.

${ }^{325}$ But see ECJ, Case C-308/06, Intertanko and Others, ECLI:EU:C:2008:312 (June 3, 2008), para. 51, https://curia.europa. eu/juris/liste.jsf?language $=$ en $\&$ num $=\mathrm{C}-308 / 06$.

${ }^{326}$ As occurred in Air Transport and ELFAA.

${ }^{327}$ See d'Aspremont \& Dopagne, supra note 31 , at 371.
} 
the international and domestic levels, d'Aspremont is more nuanced concerning interpretation; "when applying the rules of another legal order, judges should heed the rules of interpretation of that legal order ... [otherwise] judges would simply apply another rule than the rule originating in that foreign legal order." 328

With proportionality present the allure for the Court of opportunistic interpretations of international law and oscillating tests for direct effect as a means to control international law's impact would be lessened in external case law. The logic for retaining structural differences compared to internal case law concerning access to justice would also be removed. Consequently, in the future, approaches in external case law could more closely reflect those already present in internal case law discussed above. For example, in judicial review cases under Article 263 TFEU, privileged applicants such as Member States should not be dependent on direct effect of the international provision. Under Article 267 TFEU, preliminary reference questions arising concerning the legality of EU secondary legislation do not require direct effect internally, nor should they externally. Direct effect would be required to challenge Member State legislation under 267 TFEU, as is the case internally: However, direct effect of international law in Member State cases has often been found and is less uncertain as a result. These changes would helpfully restore a consistent approach to the balance between actors across both internal and external case law.

This is not to say that these changes will result in overbearing review of EU action in all instances, which should also alleviate concerns over floodgates opening to claimants. It should be remembered that the intensity in proportionality review of EU and Member State action differs. Member States often need to adopt the least restrictive path, whereas more lenience is afforded to the EU institutions. The practice of allowing a margin of appreciation to the EU legislature would seem appropriate here, given that its basis tends to be the complexity of judgements which the legislature must undertake, and International affairs are generally recognized to be an area in which the executive or legislature has wide discretion. ${ }^{329}$ Moreover, the odd potential divergence between cases such as Arcelor, concerning internal expansion of the emissions trading scheme, and Air Transport, concerning expansion of the same scheme with an international context, would be remedied. In Air Transport a margin was provided, but not based on the complexity of judgement required. Instead, unconvincingly, the uncertainty of customary international law was invoked; were the case to have concerned international treaty law binding on the EU, rather than customary law, no margin would have been provided to the legislature.

A key limitation to any margin of appreciation arrives concerning the EU's infringement of the essence of fundamental rights, and to the extent that this principle is present internally, this would continue to be the case externally. It is also submitted that the reference and implementation principles could appropriately be applied, in and beyond anti-dumping law, through proportionality, and could also affect the legislature's margin of appreciation. This seems logical as statements that EU legislation has been passed "in accordance with" or to implement international law would mean that, were legislation not to meet this aim, then it would be disproportionate, except arguably in the most complex of instances.

It can be seen that these changes would remove the need for direct effect in some cases and, in all cases, would lessen uncertainty within direct effect related rules and the need for opportunistic

\footnotetext{
${ }^{328}$ See Jean d'Aspremont, The Systemic Integration of International Law by Domestic Courts: Domestic Judges as Architects of the Consistency of the International Legal Order, in The Practice of InTERnATIONAL AND National CourTs AND THE DeFragmentation Of International LaW 152 (Ole Kristian Fauchald \& André Nollkaemper eds. 2012). See also Helmut Philipp Aust, Between Universal Aspiration and Local Application: Concluding Observations, in THE INTERPRETATION OF International Law by Domestic Courts: Unity, Diversity and Convergence 339 (Helmut Phillip Aust \& Georg Nolte eds., 2016); Wouters \& Van Eeckhoutte, supra note 235, at 207.

${ }^{329}$ Koutrakos, supra note 21 , at 183.
} 
interpretations of international law by providing a release valve in the form of proportionality. The question then becomes whether it is helpful to replace multiple small problems with one large problem; namely, what weight should be afforded to respect for international law within the case law? It is submitted that this single question was both already present and, indeed, driving the multiple oscillations and divergences present in the case law, but through a series of smaller synthetic proxies. Instead, by focusing more closely on the large question in scholarship and openly in the Court, clarity will emerge in a similar fashion to that which occurs internally concerning EU norms. Incremental arguments based within proportionality concerning respect for international law in differing contexts will inform future action in a meaningful way and will allow litigants to argue their case in alignment with the Court's underlying rationales.

\section{E. Conclusion}

What is missing from external relations case law is the capacity for the Court to engage with the facts of a case in their specific context. Though proportionality has only appeared briefly in external relations case law and scholarship to date, it does appear to be a point upon which there is gradual convergence. ${ }^{330}$ Proportionality provides a convenient means by which to distinguish specific cases without the need to avoid or mutate international law on specious bases, which has occurred in its absence. Fully embracing proportionality in external relations case law would see international law being more readily invoked. However, respect for it would be balanced against other EU norms, with the consequence that-like all EU norms-respect for international law would be extrinsically defined, through applying proportionality in specific cases, rather than intrinsically defined through vacillating assertions about international law's capability to be relied upon.

When and which EU norms should trump respect for international law? These are clearly questions for future research, and they would be facilitated by scholars openly acknowledging and promoting proportionality's relevance rather than multiplying the range of nomenclatures. Then meaningful debate on substance can begin. For instance, many would argue that a margin ought to be provided to the legislature in fields related to international law, and yet others would argue that there should be heavy presumption in favor of respecting international law. Initially, it is clear that significant fundamental rights, such as Kadi, should be more likely to be favorably weighed against international law than more minor issues within consumer protection, such as ELFAA. But there are more challenging cases, and ones which call for very delicate consideration. The balance will also necessarily change over time, as all norms develop ${ }^{331}$ and cases differ. Proportionality can accommodate this debate and the complexity, which is already inherent in the case law, whilst simultaneously providing greater legal certainty.

Balancing respect for international law against other EU norms is eminently justifiable from the perspective of international law-as states retain discretion concerning application of international law domestically. ${ }^{332}$ More generally, the diminishing esteem in which the Court's case law is held for its respectfulness towards international law means change is now opportune. ${ }^{333}$

Finally, it should be remembered that the Court is already balancing EU norms such as fundamental rights, consumer protection, environmental protection, and trade interests against

\footnotetext{
${ }^{330}$ See supra discussion accompanying notes $23-38$.

${ }^{331}$ It is submitted that the Court's vision of "trade" in external relations case law is particularly inconsistent/limited at current as is its monosyllabic tendency to find Member States in breach of international agreements. On the latter see, Mendez, supra note 4.

${ }^{332}$ See supra discussion accompanying notes $23-38$.

${ }^{333} \mathrm{But}$ see sources cited supra notes 39-53.
} 
respect for international law. However, it currently does so through the more crude and less legally certain means of oscillating direct effect tests, opportunistic interpretations, and an incoherent, autonomous legal system. So, though it does seem that there are embryonic or sporadic references to proportionality in aspects of both external relations case law and literature, it is also hoped that there is more to come on both counts. 